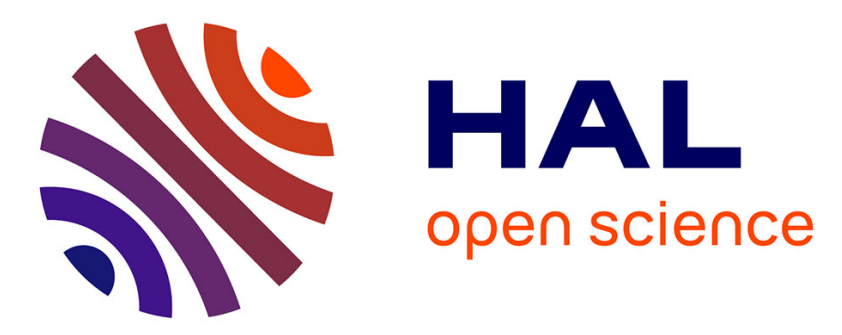

\title{
Biogeochemical processes in a clay formation in situ experiment: Part F - Reactive transport modelling
}

Christophe Tournassat, Peter Alt-Epping, Eric C. Gaucher, Thomas Gimmi, O.X. Leupin, Paul Wersin

\section{To cite this version:}

Christophe Tournassat, Peter Alt-Epping, Eric C. Gaucher, Thomas Gimmi, O.X. Leupin, et al.. Biogeochemical processes in a clay formation in situ experiment: Part F - Reactive transport modelling. Applied Geochemistry, 2011, 26, pp.1009-1022. 10.1016/j.apgeochem.2011.03.009 . hal-00597122

HAL Id: hal-00597122

https: / hal-brgm.archives-ouvertes.fr/hal-00597122

Submitted on 31 May 2011

HAL is a multi-disciplinary open access archive for the deposit and dissemination of scientific research documents, whether they are published or not. The documents may come from teaching and research institutions in France or abroad, or from public or private research centers.
L'archive ouverte pluridisciplinaire HAL, est destinée au dépôt et à la diffusion de documents scientifiques de niveau recherche, publiés ou non, émanant des établissements d'enseignement et de recherche français ou étrangers, des laboratoires publics ou privés. 


\section{Reactive transport modelling}

4 Christophe Tournassat $^{1^{*}}$, Peter Alt-Epping ${ }^{2}$, Eric C. Gaucher ${ }^{1}$, Thomas Gimmi ${ }^{2,3}$, Olivier

$6 \quad{ }^{1}$ BRGM, French Geological Survey, Orléans, France

$7 \quad{ }^{2}$ Rock-Water Interaction Group, Institute of Geological Sciences, University of Bern,

$8 \quad$ Switzerland

$9{ }^{3}$ Laboratory for Waste Management, Paul Scherrer Institut, Villigen, Switzerland

$10{ }^{4}$ NAGRA, CH-5430 Wettingen, Switzerland

$11{ }^{5}$ Gruner Ltd., CH-4020 Basel, Switzerland

$12{ }^{*}$ Corresponding author and mailing address:

13 Christophe Tournassat

14 BRGM

15 Environment and Process Division (EPI/MIS)

163 Avenue Claude Guillemin

1745060 Orléans Cedex 2, France

18 E-mail: c.tournassat@,brgm.fr

19 Tel: +33(0)238644744

$20 \quad$ Fax: $+33(0) 238643062$ 


\section{Abstract}

24 Reactive transport modelling was used to simulate solute transport, thermodynamic reactions, ion 25 exchange and biodegradation in the Porewater Chemistry (PC) experiment at the Mont Terri

26 Rock Laboratory. Simulations show that the most important chemical processes controlling the

27 fluid composition within the borehole and the surrounding formation during the experiment are 28 ion exchange, biodegradation and dissolution/precipitation reactions involving pyrite and

29 carbonate minerals. In contrast, thermodynamic mineral dissolution/precipitation reactions

30 involving alumo-silicate minerals have little impact on the fluid composition on the time-scale of

31 the experiment. With the accurate description of the initial chemical condition in the formation in

32 combination with kinetic formulations describing the different stages of bacterial activities, we

33 succeeded in reproducing the evolution of important system parameters, such as the $\mathrm{pH}$, redox

34 potential, total organic carbon, dissolved inorganic carbon and sulphate concentration. Leaching

35 of glycerol from the pH-electrode may be the primary source of organic material that initiated

36 bacterial growth, which caused the chemical perturbation in the borehole. Results from these

37 simulations are consistent with data from the over-coring and demonstrate that the Opalinus Clay

38 has a high buffering capacity in terms of chemical perturbations caused by bacterial activity. This

39 buffering capacity can be attributed to the carbonate system as well as to the reactivity of clay 40 surfaces. 


\section{Introduction}

43 Over the past two decades, reactive transport models have evolved as valuable diagnostic and

44 prognostic tools and have made a significant contribution to elucidating the inherently complex 45 dynamics of natural and engineered environments (Appelo, 1994; Steefel et al., 2003; Steefel et

46 al., 2005; Gaucher and Blanc, 2006; Appelo et al., 2008; Gaus et al., 2008; Han et al., 2010).

47 These models provide the theoretical framework for simulating coupled thermal-hydraulic-

48 chemical-biological processes within earth systems. As such, these models constitute a basis for

49 testing concepts and hypotheses and for integrating new experimental, observational and

50 theoretical knowledge about geochemical, biological and transport processes (e.g. Steefel and

51 Lichtner, 1994; Lichtner et al., 1996; Appelo et al., 1998; Maher et al., 2009).

52 The Porewater Chemistry (PC) experiment in the Mont Terri Laboratory was designed to

53 improve our understanding of the compositional characteristics and the buffering mechanisms of

54 the porewater in the Opalinus Clay. For that purpose, a vertical borehole of $52 \mathrm{~mm}$ diameter was

55 drilled to a depth of $10.10 \mathrm{~m}$. The bedding dips at an angle of about $45^{\circ}$ to the SE. The first 5

56 meters of the borehole were drilled with air. For the remaining $5.1 \mathrm{~m}$, nitrogen was used in order

57 to minimise ingress of molecular oxygen and hence oxidation of pyrite and organic matter around

58 the borehole wall. Immediately after drilling, the borehole was filled with Ar. The downhole

59 equipment including the $4.5 \mathrm{~m}$ long screen made of porous (40 $\mu \mathrm{m}$ mesh size) low pressure

60 polyethylene with a porosity of 0.3 and a $0.33 \mathrm{~m}$ long hydraulic mechanical packer was emplaced

61 into the borehole. The remaining part of the borehole was filled with epoxy resin (Sikadur 52).

62 The borehole was filled with synthetic porewater $(2.8 \mathrm{~L})$ which had been previously

63 saturated with an $\mathrm{Ar} / \mathrm{CO}_{2}$ gas mixture corresponding to a $\mathrm{pCO}_{2}$ of $10^{-3.5}$ bar, as in air. This

64 synthetic porewater was traced to keep track of transport-controlled exchange of solutes between 
65 the borehole and the surrounding formation. More details about the design and results of the 66 experiment are summarized in Wersin et al. (This Issue-a). The original focus of this experiment

67 was to obtain high-quality data on the porewater composition and thus to reduce uncertainties in $68 \mathrm{pH} / \mathrm{pCO}_{2}$ and Eh. However, unexpected microbial activity in the borehole observed after about 69 nine months led to a revised research program with the following objectives:

70 i. to identify biogeochemical processes occurring in the borehole and describe these 71 quantitatively

72 ii. to obtain diffusion parameters of injected conservative tracers

73 iii. to identify the source of organic carbon for microbial degradation

74 iv. to draw conclusions on the findings with regard to conditions of the clay host rock around a $75 \quad$ nuclear waste repository

76 To understand the complexity of processes and to identify and/or quantify crucial system 77 parameters of the PC experiment, modelling efforts were initiated by different groups involved in 78 the project. These efforts were only loosely coordinated and different groups were allowed to use 79 a software package of their choice and were free to decide on how to approach the task. 80 Consequently, it was never expected that the different groups would produce exactly the same 81 results. A summary of these modelling efforts can therefore only touch on some of the aspects 82 that had to be taken into account by the groups during the design of their model (e.g. model 83 dimensions and geometry, initial and boundary conditions, choice of parameters, choice of 84 relevance) and the reasons for differences in the model outputs.

85 The following section 2 aims at giving an overview of the reactive transport simulations 86 performed over the course of the PC-experiment. This overview serves as an introduction to a 87 model, discussed in detail in section 3 of the paper, that is almost fully capable of reproducing the 88 evolution of the borehole fluid during the five years of the experiment, as well as the observations 
89 made on the over-core samples. The geochemical and transport properties of the Opalinus clay

90 formation are then discussed in the light of modelling results.

\section{Overview of previous reactive transport simulations of the PC experiment}

94 Over the course of the PC experiment, reactive transport models that couple diffusive transport

95 with chemical reactions were designed and simulations were carried out in a collective effort by 96 different groups involved in the PC experiment. The aim was to develop models that reproduce

97 not only the time series of tracer concentrations but also time series of reactive species and the 98 evolution of the redox state and the $\mathrm{pH}$ of the borehole fluid. A model that successfully 99 represents the measured time series of borehole fluid compositions can then be used to identify 100 critical processes and to quantify system parameters and properties within the borehole as well as

101 in the surrounding rock. Furthermore, a working model can be used to make predictions about the 102 system's behaviour in the future and/or to test what-if scenarios that assess the system's response 103 to different physical or chemical conditions (ANDRA, 2005).

104 Common to all reactive transport models was the incorporation of the processes that were 105 thought to control the chemical evolution of the system: diffusive transport, ion exchange, 106 biodegradation and mineral precipitation/dissolution reactions. Even though these were 107 considered the processes driving the chemical evolution of the system, relatively little was known 108 about the relative importance of each of these processes and if and how these processes interact.

109 One aim of coupled modelling was to elucidate some of these issues.

110 Integrating transport and chemistry into a model entails a much larger number of system

111 parameters that need to be constrained than in a model that considers non-reactive transport 112 alone. Because few constraints were available for conditions in the surrounding rock, values for 
113 critical parameters regarding conditions outside the borehole could only be based on "educated

114 guesses" and were therefore associated with a large degree of uncertainty (see discussion in

115 Gaucher and Blanc, 2006). Owing to this uncertainty and other factors, which include among

116 many others: 1) the use of different software packages and geochemical datasets, 2) the choice of

117 parameters and the degree of detail, 3) the choice and the mathematical implementation of

118 processes and the couplings between them, 4) the choice of initial and boundary conditions, 5)

119 species dependent or independent diffusion, 6) uniform or species dependent accessible

120 porosities, it was expected that the results from different modelling efforts could show substantial

121 differences but should agree at least qualitatively and in some aspects quantitatively.

122 The earliest simulations that couple diffusive transport with chemical reactions were

123 carried out by Arcos et al. (2003). Reactive transport was modelled in one dimension with the

124 PHREEQC (Parkhurst and Appelo, 1999) code. These simulations already included the most

125 important processes that were thought to control the chemistry of the porewater: the degradation

126 of organic matter via sulphate reduction, ion exchange reactions and mineral

127 precipitation/dissolution reactions. Of these processes, the degradation of organic matter was

128 thought to be that which dominates the behaviour of the system in agreement with preliminary 129 microbiological analyses (Stroes-Gascoyne et al., This Issue). Biodegradation was formulated as 130

$2 \mathrm{CH}_{2} \mathrm{O}+\mathrm{SO}_{4}^{-2}=\mathrm{H}_{2} \mathrm{~S}+2 \mathrm{HCO}_{3}^{-}$

Reaction 1

132 and incorporated into the model via a Monod-type rate equation.

133 Overall, the model was able to reproduce on-line measurements of critical parameters

134 such as the $\mathrm{pH}$ and Eh reasonably well and confirmed the significance of biodegradation as the 135 most prominent process in controlling the redox evolution of the system. Discrepancies between 
136 measured and modelled data, in particular those related to sulphate and inorganic carbon, were

137 attributed to the over-simplification of the formulation for organic matter degradation, the

138 selection of the type of dissolved organic matter and the choice of kinetic parameters used in the

139 degradation reactions.

140 Tournassat and Gaucher (2004) used the PHAST code (Parkhurst et al., 2004) to simulate,

141 in $1 \mathrm{D}$, the evolution of the borehole fluid composition by using constraints from isotopic data

142 (e.g. $\delta^{13} \mathrm{C}$ ), dissolved methane, the $\mathrm{SO}_{4}^{-2}$ concentration, the $\mathrm{pH}$ and the alkalinity. They

143 concluded that methanogenic and sulphate reducing bacteria in the borehole led to a redox

144 zonation that causes methanogenesis and methane oxidation to occur simultaneously. The redox

145 state of the system is controlled by the $\mathrm{S}(-2) / \mathrm{S}(+6)$ couple, whereby the $\mathrm{S}(-2)$ and $\mathrm{S}(+6)$ activities

146 are buffered by pyrite $\left(\mathrm{FeS}_{2}\right)$ and a Fe-carbonate-phase $\left(\mathrm{FeCO}_{3}\right)$. The authors suggested that the

147 system is in a redox disequilibrium that is used by sulphate-reducing bacteria to produce

148 methane, acetate and various organic acids.

149 Grandia et al. (2006) used PHREEQC to implement a kinetic formulation for the 150 degradation of acetone through a carboxylation process:

151

$\mathrm{CH}_{3} \mathrm{COCH}_{3}+\mathrm{HCO}_{3}^{-}=2 \mathrm{CH}_{3} \mathrm{COO}^{-}+\mathrm{H}^{+}$

Reaction 2

152

153 and a Monod-type rate equation for the subsequent degradation of acetate to carbonate ions via 154 sulphate reduction:

155

$\mathrm{CH}_{3} \mathrm{COO}^{-}+\mathrm{SO}_{4}^{-2}=2 \mathrm{HCO}_{3}^{-}+\mathrm{HS}^{-}$

Reaction 3 
158 controls the Fe concentration in the borehole. All rate parameters in the biodegradation process

159 were adjusted to match the measured data from the PC experiment and the simulations were able

160 to reproduce many aspects of the evolving system.

161 Alt-Epping et al. (2006) used FLOTRAN (Lichtner, 2007) to run simulations of a

162 cylindrical model with radial coordinates, which accounted for the oblique angle between the

163 borehole and the bedding. These simulations were fully coupled, which implies that these

164 simulations also considered the feedback between porosity changes following mineral

165 dissolution/precipitation reactions and diffusive transport. This study incorporated many

166 parameters and built on results from previous studies: the formulation and selectivity coefficients

167 for ion exchange were taken from Tournassat and Gaucher (2004) and biodegradation was

168 formulated in an analogous manner to that of Grandia et al (2006). Simulations included a

169 sensitivity analysis that compared different model outcomes as a function of the initial borehole

170 fluid composition.

171 To elucidate the importance of individual reaction processes (ion exchange,

172 biodegradation, mineral dissolution/precipitation), different model scenarios included a

173 successive increase in model complexity, from the implementation of a single process only to the

174 implementation of all reaction processes and a full coupling between them. The results from the

175 simulations showed that the different initial compositions of the borehole fluid (scenarios 1-3)

176 have relatively little impact on the evolution of the system. Without ion exchange or

177 biodegradation, the reactivity of the system is low, which is consistent with very small volumes

178 of calcite, dolomite and siderite precipitation (Figure 1). Species concentrations in the borehole

179 either increase or decrease monotonously, which indicates that these changes are primarily

180 controlled by diffusive exchange with the surrounding rock (Figure 2). 
In contrast, after implementing biodegradation and ion exchange, the evolution of the

182 fluid composition in and around the borehole becomes more complex and the system has not 183 attained steady state after 1426 days. The system is more reactive, which is reflected in a larger

184 amount of precipitated carbonate minerals. The implementation of biodegradation reproduces one

185 of the key characteristics of the borehole fluid, which is the decrease in sulphur over time (Figure

186 2). In the borehole, organic matter reduces sulphate to sulphide, which subsequently diffuses

187 outward into the formation where it precipitates as pyrite (Figure 1). The uptake of sulphide into

188 pyrite outside the borehole steepens the total sulphur concentration profiles, thus enhancing 189 outward diffusion and causing a decrease in the total sulphur concentration in the borehole fluid 190 (Figure 2).

191 These results demonstrate the buffering capacity of the system, which is due primarily to 192 ion exchange and the buffering by carbonate phases. Biodegradation exerts the strongest impact 193 on the evolving fluid composition and causes the precipitation of pyrite. These simulations were

194 successful in describing qualitatively the processes occurring in the borehole and the surrounding 195 formation. The simulations also suggest that by selecting only those constituents and processes 196 that are relevant to the chemical evolution of the system, it is possible to design a "minimal" 197 model that is simple yet fully capable of reproducing quantitatively the evolution of the borehole 198 fluid during the five years of this experiment. This model is presented in the following sections.

\section{3. A simplified reactive transport model}

$2013.1 \quad$ Overview of the proposed reactive transport model

202 As stated above, the aim of this modelling exercise was to develop a "minimal" model capable of 203 reproducing the chemical evolution of the PC experiment, i.e. the chemical evolution of 204 compounds that are coupled with each other through the simultaneous occurrence of biological 
205 transformation of solute or solid compounds, in-diffusion and out-diffusion of solute species and 206 precipitation/dissolution of minerals (in the borehole and in the formation).

207 This section aims at giving an overview of the concepts and parameters used in the model. Each 208 of these parameters, including their calibration, are then discussed in the following section 4 .

Mainly because biological activities are highly non linear, processes occurring in the

210 experimental borehole could not be modelled using a purely mechanistic approach without fitting

211 parameters. Thus, it is not within the scope of this paper to try to present a biological mechanistic

212 model.

213 Different events during the course of the experiment (e.g. water sampling, leakage and 214 others) caused changing boundary conditions. As discussed elsewhere in this series of papers, the

215 major changes in the water chemistry during the PC experiment included decreasing 216 concentrations of bromide, deuterium and sulphate and increases in the organic carbon and total

217 dissolved carbonate contents. The changes in the bromide and deuterium contents were expected

218 because the test water was spiked with both of them to act as tracers. The measured

219 concentrations of these tracers in the borehole are shown in Part A, Figure 7. They differ 220 considerably from those expected in that the concentrations in samples taken late in the 221 experiment, instead of continuing to decreasing asymptotically to the low concentrations in the

222 formation water, began to increase toward those of the initial test water. This behaviour could be

223 linked to the experimental needs, where the chemical composition of the water in the borehole

224 was changed through dilution of the borehole water with volumes of synthetic water (high

225 concentration of bromide, but also zero concentration of sulphides, etc.) introduced into the

226 system to compensate the losses due to sampling or leakages. As a second consequence, these

227 events led also to changes in the concentration gradients between the borehole and the 228 surrounding formation, hence having an effect on the solute diffusion in/from the formation. It 
229 was then necessary to take these events into account in the reactive transport calculation to 230 achieve good mass balance. This was achieved by building a model with several restarts after 231 having changed the conditions in the borehole through mixing of the borehole water with 232 synthetic porewater.

233 Changing boundary conditions as a function of time had to be considered also for 234 bacterial activity. Biological analyses (Stroes-Gascoyne et al., This Issue) showed that different 235 bacterial strains with different sources of energy (e.g. sulphate reduction vs. methanogenesis) 236 were active in the borehole. Four different periods of bacterial activity can be discerned in Figure 237 3. Phase 1 is characterized by almost no release of organic matter into the system. As a 238 consequence, a low bacterial activity is expected. A significant release of organic matter different 239 from acetate is observed in phase 2, while in phase 3 there is a release of organic matter and a 240 concomitant transformation into acetate. In phase 4, the organic matter concentration in the 241 borehole decreases due to degradation into inorganic carbon and diffusion into the surrounding 242 formation, providing that the organic matter release in the borehole stopped or decreased 243 drastically. Figure 4 also shows that phase 4 must itself be subdivided into two periods for the 244 description of a bloom of methanogenesis before it slows down. This event has been recorded in 245 biological analysis through the presence of active methanogenic bacteria at the end of the 246 experiment.

Figure 3 clearly shows that acetate was not the primary source of organic carbon in the

248 system because acetate concentration is well below total or dissolved organic carbon

249 concentration before phase 3 . Acetate must therefore be considered as a secondary product of the

250 bacterial activity. This secondary product can itself be degraded into inorganic carbon, as will be

251 shown later. The nature of the primary source organic matter that was released into the borehole 252 and then transformed into acetate was the subject of much controversy over the course of the 
253 experiment: among the possible candidates, acetone $\left(\mathrm{CH}_{3}-\mathrm{CO}-\mathrm{CH}_{3}\right)$, which was used for cleaning 254 the filters before the experiment, was long preferred until modern carbon measurements on 255 dissolved organic carbon revealed that the carbon source was a modern one (De Cannière et al., 256 This issue). After thoroughly scrutinizing the potential sources of modern carbon in the system, 257 De Cannière et al. came to the conclusion that glycerol $\left(\mathrm{C}_{3} \mathrm{H}_{8} \mathrm{O}_{3}\right)$, originating from the gel $\mathrm{pH}-$ 258 electrode, was the most probable candidate as the primary source of organic carbon in the system.

259 The two samples during phase 3 exhibited acetate concentration of the same level as total 260 organic matter. Moreover, these concentrations increased during phase 3. This observation can 261 only be explained by considering that the primary source of organic carbon, once released into 262 the borehole water, is immediately converted into acetate. From a modelling conceptual point of 263 view, this behaviour is equivalent to the presence of a "solid" source of carbon that is not 264 released into solution but is directly degraded into acetate. If we consider that glycerol from the 265 electrode is indeed the primary source of carbon, this could be explained by the presence of an 266 intense bacterial activity in the vicinity of the electrode degrading glycerol into acetate. On the 267 contrary, during phase 2 , total organic carbon concentration is much higher than acetate 268 concentration, evidencing a release from the electrode that is faster than the consumption by 269 surrounding bacteria, possibly because the initial population of active bacteria was very small. As 270 a consequence, organic matter releases in the system were modelled by three distinct kinetic rates accounting for these three situations: (i) a rate for glycerol (or another organic compound) release

272 into solution, (ii) a rate for its degradation into acetate and (iii) a rate for direct release of acetate 273 into solution accounting for the rapid conversion of glycerol (or another organic compound) into 274 acetate at the source term.

275 These rates were arbitrarily changed as a function of time in order to accurately reproduce 276 the data shown in Figure 3. This approach must be seen as a purely fitting approach that is 
277 justified because the interest of the modelling was to understand the response of the system to the

278 bacterial activity.

280 3.2. Numerical modelling methods

\subsubsection{Geometry and transport}

282 In the modelling approach that follows, the experimental borehole was considered to be a perfect

283 cylinder. Diffusion taking place at the bottom and the top ends of the cylinder was neglected in 284 comparison to radial diffusion owing to the low value of their surface area as compared to radial 285 surfaces. Anisotropy of diffusion due to the bedding of the rock (Arcos et al., 2004; Van Loon et 286 al., 2004a; Van Loon et al., 2004b) was not taken explicitly into account. With this 287 approximation, the system turned into a 1D radial model. This type of geometry can be 288 implemented in PHREEQC using the "-stagnant_cells" option. (Parkhurst and Appelo, 1999;

289 Appelo, 2007; Appelo and Wersin, 2007). Transport by diffusion is solved at each time step by 290 mixing iteratively adjacent cells $(n$ and $n+1)$ following the relationship:

291

$$
\operatorname{mixf}_{n, n+1}=\varepsilon \times D_{p} \times \Delta t \times \frac{A_{n, n+1}}{h_{n, n+1} \times V_{n}} \times f_{b c}
$$

Equation 1

292 where $\varepsilon \times D_{p}$ is the harmonic mean of the effective diffusion coefficient, i.e.:

293

$\varepsilon \times D_{p}=2 \frac{\varepsilon_{n} \times D_{p, n} \times \varepsilon_{n+1} \times D_{p, n+1}}{\varepsilon_{n} \times D_{p, n}+\varepsilon_{n+1} \times D_{p, n+1}}$

Equation 2

294 where $\Delta t$ is the time step (s), $A_{n, n+1}$ is the shared surface area among cells $n$ and $n+1\left(\mathrm{~m}^{2}\right), h_{n, n+1}$ 295 is the distance between midpoints of the cells $n$ and $n+1(\mathrm{~m}), V_{n}$ is the water volume in cell $n$ for 
296 which the concentration change is calculated $\left(\mathrm{m}^{3}\right)$, and $f_{b c}$ is a correction factor that equals 2 for

297 constant concentration (end cell of the system) and 1 otherwise (inner cell of the system with

298 closed boundary). $\varepsilon_{n}(-)$ is the porosity of cell n. $D_{p, n}$ is the pore diffusion coefficient of cell $\mathrm{n}\left(\mathrm{m}^{2}\right.$

$299 \mathrm{~s}^{-1}$ ). If no surface diffusion (in the electrostatic double layer at charged mineral surfaces) is

300 considered, the pore diffusion coefficient is related to the effective diffusion coefficient $\left(D_{e}\right)$ by

301 the relationship:

302

$D_{e, n}=\varepsilon_{n} \times D_{p, n}$

Equation 3

303 The borehole was modelled using only one numerical cell representative of the ring

304 volume containing the test water (the inner part of the borehole was filled with instrumental

305 devices). Surface to volume ratios between adjacent cells were calculated according to the

306 diameter of the borehole $(0.052 \mathrm{~m})$ and the size of each numerical cell. The Opalinus Clay

307 formation was represented by 33 cells extending $1.5 \mathrm{~m}$ into the clay formation. Grid size was

308 refined when approaching the borehole/formation interface: cell sizes ranged from $0.002 \mathrm{~m}$ at the

309 interface up to $0.2 \mathrm{~m}$ in the clay formation. Considering the total length of the borehole $(4.63 \mathrm{~m})$,

310 this corresponds to a porous rock volume of $0.0016 \mathrm{~m}^{3}$ for the cell at the interface and $8.3 \mathrm{~m}^{3}$ for

311 the last cell in the clay formation. Transport parameters were fitted according to the $\mathrm{Br}$ and

312 deuterium diffusion profiles using the multicomponent diffusion option of PHREEQC (different

$313 D_{p}$ values can be attributed to different solutes in the system). All dilution events (sampling and

314 leakages reported in Wersin et al., This issue-a) were taken into account.

315

$316 \quad 3.2 .2$ Chemistry Database 
317 The BRGM Thermoddem database (http://thermoddem.brgm.fr/index.asp?langue $=\mathrm{GB}$ ) was used

318 for chemical species and minerals solubility given the need for reliable thermodynamic data of

319 clay minerals. Preliminary simulation runs made it possible to simplify calculations by removing

320 unnecessary solute species. The database used for the simulation is given in Electronic Annex 1.

321

322 3.3. Boundary conditions

$323 \quad$ 3.3.1 Anion concentration and accessible porosity

324 Because of the out-diffusion of chloride at the Lias and Dogger boundaries, porewaters of

325 the Opalinus Clay at Mont Terri show a distinct diffusion profile through the formation (See

326 Figure 2 in Wersin et al., This issue-a). The stability of the $\mathrm{Cl}+\mathrm{Br}$ concentration profile due to

327 diffusion of $\mathrm{Br}$ from the borehole in the formation and $\mathrm{Cl}$ from the formation in the borehole

328 confirmed that porewater chloride concentration was about $0.3 \mathrm{~mol} / \mathrm{L}$ (Figure 5). Sulphate

329 concentration was adjusted to match the $\mathrm{Cl} /$ sulphate seawater ratio in agreement with porewater

330 modelling results (Pearson et al., This issue).

331 Total water loss at $105^{\circ} \mathrm{C}\left(7.42-8.4 \mathrm{~kg}_{\text {water }} \mathrm{kg}_{\text {rock }}{ }^{-1}\right)$ together with rock bulk density

332 determination (2.38-2.4 $\mathrm{kg} \mathrm{dm}^{-3}$ ) enabled Koroleva et al. (This issue) to determine a mean total

333 porosity of 0.19 . This value is also in agreement with reported grain density of $2.7 \mathrm{~kg} \mathrm{dm}^{-3}$

334 (Pearson et al., 2003, Table A9.12). This porosity value is high when compared to previously

335 reported values measured with the same method (Pearson et al., 2003, Table A9.12). However, it

336 is still in agreement with porosity values obtained from HTO diffusion experiments: for instance

337 Van Loon et al. (2003) reported values up to 0.2. According to (i) this porosity value, (ii) the total

338 chloride content that can be leached from the sample and (iii) the $\mathrm{Cl}$ concentration in the

339 porewater (as given by the final concentration of the test water), Koroleva et al. (This issue) also

340 calculated that anion accessible porosity represents $\sim 75 \%$ of total porosity. This value is higher 
341 than the usually reported mean value of $\sim 50-60 \%$, but still in reasonable agreement with the

342 range of variation reported in the literature (40-70\%, Van Loon et al., 2003; Van Loon et al.,

343 2004a; Van Loon et al., 2007). As a consequence, it was decided to consider this measured value

344 in the modelling exercise. In the following, an anion accessible porosity of 0.14 corresponding to

$3450.06 \mathrm{~kg} / \mathrm{kg}_{\mathrm{r}}$ will be used and the remaining $0.02 \mathrm{~kg} / \mathrm{kg}_{\mathrm{r}}$ must be considered as "surface water"

346 (Appelo and Wersin, 2007; Appelo et al., 2008).

\subsubsection{Major cations ( $\mathrm{Na}, \mathrm{K}, \mathrm{Ca}, \mathrm{Mg}, \mathrm{Sr})$ and cation exchange}

349 A cation exchange reaction can be represented by the following reaction equation, in the case of a $350 \mathrm{Na}^{+} / \mathrm{Me}^{\mathrm{z}+}$ binary system $(\mathrm{Me}=\mathrm{K}, \mathrm{Ca}, \mathrm{Mg}$ or $\mathrm{Sr})$ :

351

$\mathrm{z} \mathrm{NaX}+\mathrm{Me}^{\mathrm{z}} \Leftrightarrow \mathrm{MeX}_{\mathrm{z}}+\mathrm{z} \mathrm{Na}$

Reaction 4

353 where $\mathrm{X}^{-}$represents a negatively charged surface site. The selectivity coefficient of this reaction 354 is $K_{G T}{ }^{N a / M e}$ :

$$
K_{G T}^{N a / C a}=\frac{\left\{N a^{+}\right\}^{z}}{\left\{M e^{z+}\right\}} \times \frac{E_{M e}}{E_{N a}^{z}}
$$

Equation 4

356 Where $E$ values are charge fractions on the exchanger.

357 The over-coring analysis showed that cation exchanger composition is very constant as a function

358 of borehole distance (Koroleva et al., This issue). In these conditions, Equation 4 implies that the

359 ratio of solute activity $\frac{\left\{\mathrm{Na}^{+}\right\}^{z}}{\left\{M e^{z+}\right\}}$ is also constant. This can be verified in Figure 6. 
361 from exchanger population analysis and borehole sample data (Table 1). These values can be

362 compared to those predicted by the illite and smectite exchanger models given by Tournassat et

363 al. (Tournassat et al., 2007; Tournassat et al., 2009). The present exchange selectivity coefficients

364 can be explained by a combination of illite and smectite surfaces: modelled $\mathrm{Na} / \mathrm{K}$ selectivity

365 coefficients are lower than the measured selectivity coefficient for illite/smectite mixed layer

366 minerals (I/S). This observation is in agreement with the recommendation of Tournassat et al.

367 (2009) to increase the $\mathrm{Na} / \mathrm{K}$ coefficient by $0.2-0.4 \log _{10}$ unit for $\mathrm{I} / \mathrm{S}$ surfaces. Exchange

368 selectivity coefficients are also in agreement with those calculated at another location with the

369 same chlorinity (BWS-A1), while they are slightly different for a location with lower chlorinity

370 (BWS-A3) (Pearson et al., This issue).

371 In the following, the $\log _{10} \mathrm{~K}_{\mathrm{GT}}$ value calculated from borehole and core samples (first

372 column of Table 1) will be used to run the simulations.

373

\subsubsection{Porewater chemistry}

375 Initial porewater chemistry was calculated at $25^{\circ} \mathrm{C}$ with the model presented in Pearson et al.

376 (This issue) and with the parameters given above. The minerals considered at equilibrium with

377 the formation porewater were: quartz, calcite, siderite, chlorite (Chlorite-CCa-2), illite

378 (Illite_IMt2) and pyrite. Chosen chlorite and illite data were originally obtained from calorimetric

379 measurements (Gailhanou et al., 2007; Gailhanou et al., 2009). Porewater modelling results are

380 given in Table 2Erreur ! Source du renvoi introuvable..

381

382

3.3.4 $\mathrm{HDO}$ and $\mathrm{Br}^{-}$diffusion 
384 studied at the laboratory scale (Van Loon et al., 2004a) as well as in in-situ experiments (Van 385 Loon et al., 2004b). Van Loon et al., 2004b report a diffusion coefficient ( $\left.\mathrm{D}_{\mathrm{p}}\right)$ of $1.110^{-10}$ and 2.7

$38610^{-10} \mathrm{~m}^{2} \mathrm{~s}^{-1}$ for $\mathrm{I}^{-}$and HTO respectively. Together with the measured accessible porosity 387 (Koroleva et al., This issue), these values were used in our calculations and then slightly adjusted 388 to better match the data. A good fit was obtained with $\mathrm{D}_{\mathrm{p}}$ of $0.910^{-10}$ and $2.410^{-10} \mathrm{~m}^{2} \mathrm{~s}^{-1}$ for $\mathrm{Br}^{-}$ 389 and HDO respectively (Figure 7).

390 Koroleva et al. (This issue) report spatial profiles of $\mathrm{Br}$ and $\mathrm{Cl}$ concentrations in the 391 immediate vicinity (first 17 centimetres) of the borehole. Even though the data, in particular the 392 data for $\mathrm{Cl}^{-}$, are associated with a relatively large degree of uncertainty, there appears to be a 393 discrepancy between the computed (with diffusivities estimated from time-series of tracer 394 concentrations in the borehole fluid) and measured spatial profiles (Figure 7, lower right panel).

395 It is not easy to decide whether this shift is significant or not. If significant, this shift would 396 suggest the presence of a disturbed zone surrounding the borehole having enhanced diffusion 397 properties (Cartalade et al., 2007). Considering the overall good agreement of the model and the 398 measured data and their associated uncertainty, the possibility of a disturbed zone is not further 399 discussed.

400 In the following models, a porosity corresponding to the volume of $75 \%$ of the total water 401 content (i.e. volumetric porosity $=0.14$ ) was assumed for the entire rock formation. In the 402 proposed reactive transport model, this porosity applies not only to anions but also to positively 403 charged and neutral species for simplicity and calculation time saving reasons. By the way, 404 considering the total porosity instead of the reduced porosity for HDO transport has little effect 405 on the calculated HDO concentrations as a function of time in the borehole (Figure 7). It is 406 possible to consider different $\mathrm{D}_{\mathrm{p}}$ for different solute species using the multi-component diffusion 
407 option of PHREEQC (Appelo and Wersin, 2007). Differences in $\mathrm{D}_{\mathrm{p}}$ originate from differences in

408 the diffusion coefficient in pure water $\left(\mathrm{D}_{0}\right)$ and tortuosity $(\tau)$ for different solute species. For each

409 species $i$, the relationship $\mathrm{D}_{\mathrm{p}}=\tau \mathrm{D}_{0}$ applies. In the present studies, $\mathrm{D}_{0}$ values from the Phreeqd.dat

410 database were considered together with a tortuosity factor calculated from experimental $\mathrm{D}_{\mathrm{p}}$ for $\mathrm{Br}$

411 and HTO: we set the tortuosity ( $\tau$ ) for anions and neutral species as $\tau_{\text {anions }}=D_{p}(B r) / D_{0}(B r)$ and

$412 \tau_{\text {neutral }}=D_{p}(H D O) / D_{0}(H D O) . \mathrm{D}_{0}$ for $\mathrm{OH}^{-}$and $\mathrm{H}^{+}$were set to the value of $\mathrm{HDO}$ for calculation time

413 saving reasons. As a further simplification of the system, we considered that the same tortuosities

$414 \tau_{\text {anions }}$ applied to all of the anions, independently of their charge and $\tau_{\text {neutral }}$ to both neutral species

415 and cations. Cations are expected to have lower tortuosities than neutral species (Appelo and

416 Wersin, 2007) but this effect was neglected.

\section{3.4. Borehole conditions}

$419 \quad 3.4 .1 \quad$ Biological activity kinetic parameters

420 Once the solute species diffusion properties were fixed, six kinetic parameters for material

421 degradation and bacterial activity could be fitted: three of them account for the release of the 422 primary organic matter and its transformation into acetate (see section 2); two others are for 423 sulphate reduction/acetate oxidation and the last one is for methanogenesis. Each of these 424 parameters was constrained by measured data:

425 - The release rate of primary organic carbon source in solution can be computed through

426 the difference between TOC (total organic carbon) and acetate concentrations.

427 - The degradation rate of this organic carbon together with the degradation rate of a "solid" 428 carbon source into acetate was fitted with the acetate concentrations as a function of time. 
- The sulphate reduction rate (through acetate oxidation) was constrained by sulphate concentration as a function of time.

- The rate of methane production from acetate degradation was given by the methane concentration profile as a function of time.

435 system with all of the intermediate degradation products and no attempt has been made to find 436 them in the literature. Measurable initial and final products solely were considered, as well as 437 zero-order kinetic reactions. Bacteria are considered here only as catalysts for thermodynamically 438 possible reactions.

439 Glycerol (described as $\mathrm{C}_{3} \mathrm{H}_{8} \mathrm{O}_{3}$ ) transformation into acetate was described with: 440

$2 / 7 \mathrm{C}_{3} \mathrm{H}_{8} \mathrm{O}_{3}+1 / 7 \mathrm{HCO}_{3}^{-} \Rightarrow 1 / 2 \mathrm{CH}_{3} \mathrm{COO}^{-}+5 / 14 \mathrm{H}^{+}+2 / 7 \mathrm{H}_{2} \mathrm{O}$

Reaction 5

441 Even though it is now clear that the source of carbon in the system was glycerol that leached 442 from the electrode (De Cannière et al., This issue), the question regarding the nature of this 443 source was also addressed through this reactive transport model exercise by considering two 444 other potential sources of carbon. One of these potential sources was acetone that could have 445 entered into the system after the filter cleaning procedure (De Cannière et al., This issue): 446

$1 / 4 \mathrm{CH}_{3}-\mathrm{CO}-\mathrm{CH}_{3}+1 / 4 \mathrm{HCO}_{3}^{-} \Rightarrow 1 / 2 \mathrm{CH}_{3} \mathrm{COO}^{-}+1 / 4 \mathrm{H}^{+}$ Reaction 6 
448 as a generic $\mathrm{CH}_{2} \mathrm{O}$ formula:

449

$$
\mathrm{CH}_{2} \mathrm{O} \Rightarrow 1 / 2 \mathrm{CH}_{3} \mathrm{COO}^{-}+1 / 2 \mathrm{H}^{+}
$$

Reaction 7

450 The sensitivity of the modelling result to the considered source of carbon could then be tested.

451 Acetate degradation during sulphate reduction was described with

452

$\mathrm{CH}_{3} \mathrm{COO}^{-}+\mathrm{SO}_{4}{ }^{2-} \Rightarrow 2 \mathrm{HCO}_{3}^{-}+\mathrm{HS}^{-}$

Reaction 8

453 and methanogenesis with:

454

$\mathrm{CH}_{3} \mathrm{COO}^{-}+\mathrm{H}_{2} \mathrm{O} \Rightarrow \mathrm{HCO}_{3}^{-}+\mathrm{CH}_{4}$

Reaction 9

456 Table 1 in Electronic Annex 2 gives the fitted parameters for all of these reactions. Reaction 5 to

457 Reaction 9 were normalized to $1 / 2$ acetate (corresponding to 1 organic carbon atom). Changes in 458 kinetic rates were defined at each experimental event.

459 Figure 8 shows the good agreement (because fitted) between modelled concentrations in 460 the borehole as a function of time for organic compounds, sulphate and methane.

\subsubsection{Mineral precipitation/dissolution}


463 Due to the intense bacterial activity, a large amount of sulphide has been produced that has

464 precipitated as FeS compounds and pyrite (Koroleva et al., This issue). According to speciation

465 calculations using experimental data ( $\mathrm{pH}, \mathrm{Fe}(\mathrm{II})$ and sulphide concentration when available),

466 pyrite was oversaturated. As a consequence, pyrite could not be considered at equilibrium in the

467 simulation. According to the fast kinetic of precipitation for FeS in the experimental conditions

468 (Rickard, 1995) with regards to the simulation time-step, we decided to consider equilibrium for

469 a FeS compound:

470

$\mathrm{FeS}+\mathrm{H}^{+} \Rightarrow \mathrm{Fe}^{2+}+\mathrm{HS}^{-} \quad$ Reaction

471 The solubility $\mathrm{K}_{\mathrm{FeS}}$ of the compound was fixed at the mackinawite solubility tabulated in the 472 database $\left(\log _{10} \mathrm{~K}_{\mathrm{FeS}}=-3.54\right)$. Pyrite precipitation was considered as a kinetic process linked to 473 the abundance of FeS (Rickard and Luther III, 2007). The rate of pyrite precipitation had little 474 influence on the outcome of the simulation with regards to simulated $\mathrm{Fe}$ and sulphide 475 concentrations in the borehole. The only effect is on the FeS/pyrite ratio of precipitated minerals.

476 Unfortunately no quantitative data is available for this parameter.

477 Calcite was found to precipitate in the borehole as well (Koroleva et al., This issue), in 478 agreement with its saturation index calculated from alkalinity, $\mathrm{pH}$ and $\mathrm{Ca}$ concentration (Figure 479 9). Calcite was oversaturated during the whole of the experiment due to (i) kinetic limitation for 480 its precipitation and/or (ii) measurement uncertainties and/or (iii) uncertainties in the database 481 with regards to the solute complex of $\mathrm{Ca}$. We took these effects into account by considering that 482 calcite precipitated in the borehole at thermodynamic equilibrium but with a saturation index of $483 \quad 0.2$ instead of 0. 


\subsection{3 $\mathrm{pH}$ buffer effect of clay mineral surfaces}

486 The $\mathrm{pH}$ buffer effect of clay minerals was taken into account by considering the clay 2-pK non 487 electrostatic model of Bradbury and Baeyens (Bradbury and Baeyens, 1997). The amounts of 488 sites were recalculated from the measured amount of illite + illite/smectite in the rock $(\sim 38 \%$, 489 Koroleva et al., This issue). We considered that illite and smectite sites have nearly the same 490 buffer properties (Bradbury and Baeyens, 2009a; Bradbury and Baeyens, 2009b). In addition, we 491 considered that $\mathrm{H}^{+}$could undergo cation exchange reaction with the same affinity for the surface 492 as $\mathrm{Na}^{+}$(Laudelout et al., 1968; Ferrage et al., 2005). The effect of compaction on site accessibility in the intact rock material was not taken into account.

\section{4. $\quad$ Results and discussion}

\subsection{Influence of the nature of the organic matter on modelling results}

497 Once organic matter production and degradation rates have been determined, the effect of these 498 reactions can be assessed on key parameters such as $\mathrm{pH}$ and alkalinity. However, these 499 parameters are potentially highly buffered by the surrounding formation. In a first attempt, we 500 considered the $\mathrm{pH}$ buffer of the clay surfaces as described above together with the equilibrium of 501 the formation with its calcite and siderite constituents. No other mineral in the formation was 502 introduced into the model. Figure 10 shows that the consideration of $\mathrm{CH}_{2} \mathrm{O}$, glycerol or acetone 503 as the primary source of carbon has a significant effect on the result. Modelled alkalinity 504 increases in the order acetone $<$ glycerol $<\mathrm{CH}_{2} \mathrm{O}$. Conversely, $\mathrm{pH}$ decreases in the order acetone $505>$ glycerol $>\mathrm{CH}_{2} \mathrm{O}$. These relationships can be easily appreciated through the consideration of 506 combinations of reactions 11 to 14 that all concern organic matter degradation via sulphate 507 reduction: 
$4 / 7 \mathrm{C}_{3} \mathrm{H}_{8} \mathrm{O}_{3}+\mathrm{SO}_{4}{ }^{2-} \Rightarrow \mathrm{CH}_{3} \mathrm{COO}^{-}+5 / 7 \mathrm{H}^{+}+4 / 7 \mathrm{H}_{2} \mathrm{O}+12 / 7 \mathrm{HCO}_{3}{ }^{-}+\mathrm{HS}^{-} \quad$ Reaction

511 For each sulphate mole that is transformed into sulphide in these reactions, glycerol produces 1.7

512 moles of bicarbonate, $\mathrm{CH}_{2} \mathrm{O}, 2$ moles and acetone, 1.5 moles. The evolution is similar for $\mathrm{pH}$ : the

513 acetone case, with $0.5 \mathrm{H}^{+}$produced per mole of sulphate, exhibits logically the highest $\mathrm{pH}$ while

514 the $\mathrm{CH}_{2} \mathrm{O}$ case led to the most acidic result with $1 \mathrm{H}^{+}$per sulphate molecule. Glycerol produces

$5150.7 \mathrm{H}^{+}$per sulphate and leads to an intermediate result between $\mathrm{CH}_{2} \mathrm{O}$ and acetone.

516 Whereas, in all cases, $\mathrm{pH}$ predicted by the simulation is in general agreement with 517 measured $\mathrm{pH}$, TIC and alkalinity are best reproduced with the glycerol model (Figure 10). This

518 result is in agreement with the results of De Cannière et al. (This issue), who demonstrate that 519 glycerol is the best candidate for organic source in the system.

\subsection{Influence of the $\mathrm{pH}$ buffer from the formation}

522 The test-case without clay surface $\mathrm{pH}$ buffering in the formation revealed that this buffer has an

523 important effect on the outcome of the simulation: without this buffering effect, total inorganic

524 carbon concentration increases too much while the $\mathrm{pH}$ is too low (Figure 11). The results remain 
525 however in good agreement with the measurements. Increasing the buffering capacity by a factor

526 of three has little effect on the results (Figure 11): as a consequence, the present experiment

527 cannot be used to finely determine this buffering capacity although it confirms its existence. With

528 regard to our boundary conditions, the $\mathrm{pH}$ of the porewater is a parameter whose uncertainty

529 must be addressed: measured and modelled $\mathrm{pH}$ values up to 7.5 have been reported (Pearson et

530 al., This issue). An additional simulation was run with an initial $\mathrm{pH}$ of 7.4 in the porewater of the

531 formation. The alkalinity value was adjusted accordingly to achieve equilibrium with calcite

532 without changing the calcium concentration. This change has a marked effect on the modelling

533 result (Figure 11) with too low inorganic carbon concentration and too high $\mathrm{pH}$ : as a

534 consequence, at the location of the experiment, the $\mathrm{pH}$ of the porewater is rather at a value of 7

535 than 7.5. The outcome of this sensitivity analysis is summarized in Table 3.

\subsection{Iron and sulphide controls}

538 Iron and sulphide concentrations are not well reproduced by the model as a function of time

539 (Figure 12). It should be noted that the maximum concentration of sulphide at day 600 in the

540 system is in agreement with the solubility of mackinawite representative here of an "amorphous"

541 FeS compound (note that, at that time, the predicted iron concentration is not too much in error).

542 It was however neither possible to reproduce the decrease in sulphides after day 600 , nor the

543 strong increase in iron concentration at day 1061. The iron and sulphide systems are highly

544 oscillatory and it is thus difficult to describe them with an equilibrium approach. In particular, the

545 peak of sulphide concentration is fully correlated with the peak in acetate concentration, although

546 the precipitated FeS in the borehole should have buffered its concentration as shown by the

547 model. Potential degassing (departure of $\mathrm{H}_{2} \mathrm{~S}$ ) and introduction of atmospheric $\mathrm{O}_{2}$ during the 
548 leakage events were not taken into account in the simulations and could have played a role in the

549 control of the sulphide concentration.

550 With regards to iron, the presence of organic chelates in solution, originating from

551 bacterial activity, could be an explanation for its too high measured concentration as compared to

552 the model.

\subsection{Concentrations of major cations}

555 Major cations (Na, Ca, Mg, K, Sr) are adequately described by the model (Figure 13). This result 556 was fully expected since the porewater composition was calculated in agreement with their 557 concentrations that remained almost constant in the borehole during the experiment. It may be 558 noted that the modelled calcium concentration decreases with time in the borehole and with an 559 evolution parallel to the measured concentration. A slight increase in the Ca concentration in the 560 porewater (corresponding to a small decrease in the exchange selectivity coefficient for $\mathrm{Ca}$ )

561 together with an increase in the saturation index of calcite would make it possible to reproduce 562 almost perfectly the data (not shown).

\subsection{Comparisons with over-coring data}

565 Mineralogical and chemical data obtained from over-coring sampling did not show

566 significant changes in the composition of the clayrock material directly surrounding the

567 experiment in spite of the dramatic changes of concentration of some elements in the borehole

568 (e.g. sulphate, sulphur, $\mathrm{pH}$ and total inorganic carbon). Conversely, the analysis of mineralogical

569 phases having precipitated inside the borehole revealed the high reactivity of the system. This

570 type of contrasting information between clay-rock and borehole is direct proof of the high 
571 buffering capacity of the rock with regard to chemical perturbations and it can be further

572 ascertained from the analysis of reactive transport modelling outcomes.

573 The precipitation of "amorphous" sulphide mineral in the borehole together with a

574 kinetically controlled precipitation of pyrite was an input condition for the modelling. The

575 important information obtained from the modelling work is that (i) sulphide minerals can

576 effectively precipitate (from the thermodynamic and kinetic points of view) and (ii) that more

577 than $99.9 \%$ of amorphous sulphide mineral precipitated at the interface. Figure 14 illustrates the

578 presence of a zone enriched in precipitates at the borehole/clay formation interface (the y-axis is

579 in log scale). Detachment of minerals from this zone due to water circulation causing erosion of

580 the borehole wall could explain the massive presence of sulphide minerals at the bottom of the

581 borehole and in the circulation tubes at the end of the experiment. This simulation result also

582 explains why it was not possible to detect precipitation of such phases inside the clayrock

583 formation.

584 While calcite precipitation has been observed in the borehole, it was not possible to detect 585 any newly precipitated calcite in the first centimetres of the formation. The simulations are also

586 in agreement with this observation, since only the borehole shows significant change in its calcite

587 content $\left(8.85 \mathrm{mmol} \mathrm{L}^{-1}\right.$ were precipitated in the borehole according to simulation results). The

588 maximum relative increase in calcite content is at the interface and accounts only for $0.3 \%$ of the

589 initial amount of calcite. Accordingly, the change of $\mathrm{pH}$ in the formation is rapidly buffered as 590 shown in Figure 15.

591

592 5. Conclusions

593 Reactive transport modelling simulation of the porewater chemistry experiment at Mont Terri 594 proved to be efficient in reproducing a complex set of chemical analyses as a function of time. 
595 The good agreement between the model and the measurements performed in the borehole water

596 and also in samples from over-coring enables the following conclusions to be drawn:

597 (i) The Opalinus Clay rock formation has a high buffering capacity with regard to chemical

598 perturbation due to bacterial activity: sulphur production as well as $\mathrm{pH}$ decrease or alkalinity

599 increase was buffered within a few centimetres around the borehole. This buffering capacity is

600 attributed to the carbonate system as well as to the clay surfaces reactivity.

601 (ii) The chemical controls of $\mathrm{pH}$ and major cations and anions in Opalinus Clay porewater

602 chemistry are now well constrained (Pearson et al., This issue), enabling realistic simulations of a

603 perturbed system thanks to an accurate description of the initial unperturbed system.

604 (iii) Reactive transport models proved to be useful in discriminating between hypotheses with 605 regard to different reactive pathways (e.g. different sources of organic carbon for bacteria in this 606 experiment).

607 Of course, it is not possible to prove that the proposed model is the unique solution to the 608 system with regards to the numerous parameters that are (or could be) included. The present work 609 only shows that it is possible to reproduce all main outcomes of a chemical perturbation in a clay 610 host-rock with a model that takes into account the state of the art on chemical controls in these 611 rocks. Potential applications of this model are discussed in the next synthesis paper (Wersin et al., 612 This issue-b).

613

\section{Acknowledgements}

615 This work was undertaken in close co-operation with, and with the financial support of, the Mont 616 Terri Consortium. We appreciate fruitful discussions with Agnes Vinsot, Suzanne Mettler, Pierre 617 De Cannière, David Arcos, Urs Mader, Nick Waber and Sim Stroes-Gascoyne during the 
618 Porewater Chemistry experiment. Many thanks also to the Mont Terri team, including Christophe

619 Nussbaum and Paul Bossart (Swisstopo), for their continuous support to the project.

620 


\section{References}

Alt-Epping, P., Gimmi, T., and Waber, H. N., 2006. Porewater Chemistry (PC) Experiment at Mt. Terri, Switzerland: Reactive transport simulations. NAGRA Technical Note, TN 2006-66.

ANDRA, 2005. Référentiel du comportement des radionucléides et des toxiques chimiques d'un stockage dans le Callovo-Oxfordien jusqu'à l'Homme. Dossier 2005 Argile. Agence Nationale pour la gestion des déchets radioactifs, Châtenay-Malabry, France.

Appelo, C. A. J., 1994. Some Calculations on Multicomponent Transport with Cation-Exchange in Aquifers. Ground Water 32, 968-975.

Appelo, C. A. J., 2007. Multicomponent diffusion modeling in clay systems with application to the diffusion of tritium, iodide, and sodium in Opalinus clay. Supporting information.

Appelo, C. A. J., Verweij, E., and Schäfer, H., 1998. A hydrogeochemical transport model for an oxidation experiment with pyrite/calcite/exchangers/organic matter containing sand. Appl. Geochem. 13, 257-268.

Appelo, C. A. J., Vinsot, A., Mettler, S., and Wechner, S., 2008. Obtaining the porewater composition of a clay rock by modeling the in- and out-diffusion of anions and cations from an in-situ experiment. J. Contam. Hydrol. 101, 67-76.

Appelo, C. A. J. and Wersin, P., 2007. Multicomponent diffusion modeling in clay systems with application to the diffusion of tritium, iodide, and sodium in Opalinus clay. Environ. Sci. Technol. 41, 5002-5007.

Arcos, D., 2003. Porewater chemistry (PC) experiment: Results of the geochemical modelling. Mont Terri Project TN 2003-18.

Arcos, D., Gimmi, T., Duro, L., and Waber, H. N., 2004. Modelling of tracer behaviour and dominant reactions during the pore water chemistry (PC) experiment in the Opalinus Clay, Switzerland. 11th Water-Rock Interaction Congress, Saratoga Springs.

Bradbury, M. H. and Baeyens, B., 1997. A mechanistic description of Ni and Zn sorption on Namontmorillonite. Part II: modeling. J. Contam. Hydrol. 27, 223-248.

Bradbury, M. H. and Baeyens, B., 2009a. Sorption modelling on illite Part I: Titration measurements and the sorption of Ni, Co, Eu and Sn. Geochim. Cosmochim. Acta 73, 990-1003.

Bradbury, M. H. and Baeyens, B., 2009b. Sorption modelling on illite. Part II: Actinide sorption and linear free energy relationships. Geochim. Cosmochim. Acta 73, 1004-1013.

Cartalade, A., Montarnal, P., Filippi, M., Mugler, C., Lamoureux, M., Martinez, J. M., Clement, F., Wileveau, Y., Coelho, D., and Tevissen, E., 2007. Application of inverse modeling methods to thermal and diffusion experiments at Mont Terri Rock laboratory. Physics and Chemistry of the Earth 32, 491-506.

Courdouan, A., Christl, I., Meylan, S., Wersin, P., and Kretzschmar, R., 2007. Characterization of dissolved organic matter in anoxic rock extracts and in situ pore water of the Opalinus Clay. Appl. Geochem. 22, 2926-2939.

De Cannière, P., Schwarzbauer, J., Höhener, P., Lorenz, G., Salah, S., Leupin, O. X., and P., W., This issue. Biogeochemical processes in a clay formation in-situ experiment: Part C - 
664

665

666

667

668

669

670

671

672

673

674

675

676

677

678

679

680

681

682

683

684

685

686

687

688

689

690

691

692

693

694

695

696

697

698

699

700

701

702

703

704

705

706

707

708

709

Organic contamination and leaching data in porewater chemistry experiment at Mont Terri Rock laboratory Appl. Geochem.

Ferrage, E., Tournassat, C., Rinnert, E., and Lanson, B., 2005. Influence of pH on the interlayer cationic composition and hydration state of Ca-montmorillonite: Analytical chemistry, chemical modelling and XRD profile modelling study. Geochim. Cosmochim. Acta 69, 2797-2812.

Gailhanou, H., van Miltenburg, J. C., Rogez, J., Olives, J., Amouric, M., Gaucher, E. C., and Blanc, P., 2007. Thermodynamic properties of anhydrous smectite MX-80, illite IMt-2 and mixed-layer illite-smectite ISCz-1 as determined by calorimetric methods. Part I: Heat capacities, heat contents and entropies. Geochim. Cosmochim. Acta 71, 5463-5473.

Gailhanou, H., van Miltenburg, J. C., van Genderen, A., Rogez, J., Greneche, J. M., Gilles, C., Gaucher, E. C., and Blanc, P., 2009. Thermodynamic properties of ripidolite CCa-2. Part I. Heat capacities, heat contents and entropies. Geochim. Cosmochim. Acta 73, 47384749.

Gaucher, E. C. and Blanc, P., 2006. Cement/clay interactions - A review: Experiments, natural analogues, and modeling. Waste Management 26, 776-788.

Gaus, I., Audigane, P., Andre, L., Lions, J., Jacquemet, N., Dutst, P., Czernichowski-Lauriol, I., and Azaroual, M., 2008. Geochemical and solute transport modelling for CO2 storage, what to expect from it? International Journal of Greenhouse Gas Control 2, 605-625.

Grandia, F., Domènech, C., and Arcos, D., 2006. Pore water chemistry (PC) experiment: Results of the geochemical modelling. ENVIROS report, R-2225.1.

Han, W. S., McPherson, B. J., Lichtner, P. C., and Wang, F. P., 2010. Evaluation of trapping mechanisms in geologic $\mathrm{CO}_{2}$ sequestration: case study of sacroc northern platform, a 35Year Co2 injection site. Am. J. Sci. 310, 282-324.

Koroleva, M., Lerouge, C., Mäder, U., Claret, F., and Gaucher, E. C., This issue. Biogeochemical processes in a clay formation in-situ experiment: Part B - Results from overcoring and evidence of strong buffering by the rock formation Appl. Geochem.

Laudelout, H., Van Bladel, R., Bolt, G. H., and Page, A. L., 1968. Thermodynamics of heterovalent cation exchange reactions in a montmorillonite clay. Transactions of the Faraday Society 64, 1477-1488.

Lichtner, P. C., 2007. FLOTRAN Users Manual: Two-phase non-isothermal coupled thermalhydrologic-chemical (THC) reactive flow and transport code, Version 2 Los Alamos National Laboratory, Los Alamos, New Mexico.

Lichtner, P. C., Steefel, C. I., and Oelkers, E. H., 1996. Reactive transport in porous media. Mineralogical Society of America.

Maher, K., Steefel, C. I., White, A. F., and Stonestrom, D. A., 2009. The role of reaction affinity and secondary minerals in regulating chemical weathering rates at the Santa Cruz Soil Chronosequence, California. Geochim. Cosmochim. Acta 73, 2804-2831.

Parkhurst, D. L. and Appelo, C. A. J., 1999. User's guide to PHREEQC (Version 2) - A computer program for speciation, batch-reaction, one-dimensional transport, and inverse geochemical calculations Water-resources investigations.

Parkhurst, D. L., Kipp, K. L., Engesgaard, P., and Charlton, S. R., 2004. PHAST- A program for simulating ground-water flow, solute transport, and multicomponent geochemical reactionsTechniques and Methods 6-A8. U.S. Geological Survey.

Pearson, F. J., Arcos, D., Boisson, J.-Y., Fernandez, A. M., Gäbler, H.-E., Gaucher, E., Gautschi, A., Griffault, L., Hernan, P., and Waber, H. N., 2003. Mont Terri project - Geochemistry 
of water in the Opalinus clay formation at the Mont Terri Rock Laboratory. Geology Series No. 5 Swiss Federal Office fo Water and Geology. Bern.

Pearson, F. J., Tournassat, C., and Gaucher, E. C., This issue. Equilibrium controls on chemistry of pore water from the Opalinus Clay, Mont Terri Underground Research Laboratory, Switzerland. Appl. Geochem.

Rickard, D., 1995. Kinetics of FeS precipitation: Part 1. Competing reaction mechanisms. Geochim. Cosmochim. Acta 59, 4367-4379.

Rickard, D. and Luther III, G. W., 2007. Chemistry of iron sulfides. Chemical Reviews 107, 514562.

Steefel, C. I., Carroll, S., Zhao, P., and Roberts, S., 2003. Cesium migration in Hanford sediment: a multisite cation exchange model based on laboratory transport experiments. J. Contam. Hydrol. 67, 219-246.

Steefel, C. I., DePaolo, D. J., and Lichtner, P. C., 2005. Reactive transport modeling: An essential tool and a new research approach for the Earth sciences. Earth and Planetary Science Letters 240, 539-558.

Steefel, C. I. and Lichtner, P. C., 1994. Diffusion and reaction in rock matrix bordering a hyperalkaline fluid-filled fracture. Geochim. Cosmochim. Acta 58, 3595-3612.

Stroes-Gascoyne, S., Sergeant, C., Schippers, S., Hamon, C. V., Nèble, S., Vesvres, M.-H., Barsotti, V., Poulain, S., and Le Marrec, C., This Issue. Biogeochemical processes in a clay formation in-situ experiment: Part D - Microbial analyses - Synthesis of results. Appl. Geochem.

Tournassat, C., Gailhanou, H., Crouzet, C., Braibant, G., Gautier, A., and Gaucher, E. C., 2009. Cation exchange selectivity coefficient values on smectite and mixed-layer illite/smectite minerals Soil Sci. Soc. Am. J. 73, 928-942.

Tournassat, C., Gailhanou, H., Crouzet, C., Braibant, G., Gautier, A., Lassin, A., Blanc, P., and Gaucher, E. C., 2007. Two cation exchange models for direct and inverse modelling of solution major cation composition in equilibrium with illite surfaces. Geochim. Cosmochim. Acta 71, 1098-1114.

Tournassat, C. and Gaucher, E., 2004. Progress in modelling PC-experiment results including thermodynamics, kinetics, micro-organism activity and isotopic fractionation considerations. BRGM/RP-53395-FR, NAGRA/TN 2004-72.

Van Loon, L. R., Glaus, M. A., and Müller, W., 2007. Anion exclusion effects in compacted bentonites: Towards a better understanding of anion diffusion. Appl. Geochem. 22, 25362552.

Van Loon, L. R., Soler, J. M., Jakob, A., and Bradbury, M. H., 2003. Effect of confining pressure on the diffusion of $\mathrm{HTO},{ }^{36} \mathrm{Cl}^{-}$and ${ }^{125} \mathrm{I}^{-}$in a layered argillaceous rock (Opalinus Clay): diffusion perpendicular to the fabric. Appl. Geochem. 18, 1653-1662.

Van Loon, L. R., Soler, J. M., Muller, W., and Bradbury, M. H., 2004a. Anisotropic diffusion in layered argillaceous rocks: a case study with Opalinus Clay. Environ. Sci. Technol. 38, 5721-5728.

Van Loon, L. R., Wersin, P., Soler, J. M., Eikenberg, J., Gimmi, T., Hernan, P., Dewonck, S., and Savoye, S., 2004b. In-situ diffusion of HTO, ${ }^{22} \mathrm{Na}^{+}, \mathrm{Cs}^{+}$and I- in Opalinus Clay at the Mont Terri underground rock laboratory. Radiochim. Acta 92, 757-763.

Wersin, P., Leupin, O. X., Mettler, S., Gaucher, E. C., Mäder, U., De Cannière, P., Vinsot, A., Gäbler, H. E., Kunimaro, T., Kiho, K., and Eichinger, L., This issue-a. Biogeochemical processes in a clay formation in-situ experiment: Part A - Overview, experimental design 
and water data of an experiment in the Opalinus Clay at the Mont Terri Underground Research Laboratory, Switzerland. Appl. Geochem.

759

Wersin, P., Stroes-Gascoyne, S., Pearson, F. J., Tournassat, C., Leupin, O. X., and Schwyn, B., This issue-b. Biogeochemical processes in a clay formation in-situ experiment: Part G -

761

762 
764 Table 1. Calculated and predicted selectivity coefficient for Na/Me exchange on Opalinus Clay.

\begin{tabular}{|l|l|l|l|l|l|}
\hline Exchange & Calculated & Predicted & Predicted & Calculated & Calculated \\
& $\begin{array}{l}\log _{10} \mathrm{~K}_{\mathrm{GT}} \text { from } \\
\text { borehole and } \\
\text { core sample } \\
\text { analysis }\end{array}$ & $\begin{array}{l}\log _{10} \mathrm{~K}_{\mathrm{GT}} \text { for } \\
\text { illite surfaces } \\
\text { (from a) }\end{array}$ & $\begin{array}{l}\log _{10} \mathrm{~K}_{\mathrm{GT}} \text { for } \\
\text { smectite } \\
\text { surfaces } \\
\text { (from b) }\end{array}$ & $\begin{array}{l}\log _{10} \mathrm{~K}_{\mathrm{GT}} \text { for } \\
\text { BWS-A1 }\end{array}$ & $\begin{array}{l}\log _{10} \mathrm{~K}_{\mathrm{GT}} \text { for } \\
\text { sWS-A3 }\end{array}$ \\
& & & & water (from \\
samples & water (from \\
& $1.40 \pm 0.05$ & 0.96 & 0.96 & 1.32 & 1.26 \\
\hline $\mathrm{Na} \rightarrow \mathrm{K}$ & $0.78 \pm 0.06$ & 0.41 & 0.99 & 0.83 & 0.63 \\
\hline $\mathrm{Na} \rightarrow \mathrm{Ca}$ & $0.62 \pm 0.05$ & 0.71 & 0.75 & 0.61 & 0.48 \\
\hline $\mathrm{Na} \rightarrow \mathrm{Mg}$ & $1.14 \pm 0.22$ & - & 1.17 & 0.97 & 0.51 \\
\hline $\mathrm{Na} \rightarrow \mathrm{Sr}$ & & & & & \\
\hline
\end{tabular}

a. Tournassat et al., 2007

766 b. Tournassat et al., 2009, including effects of cation-chloride ion pairs

767 c. Pearson et al., this volume 


\begin{tabular}{|c|c|c|}
\hline & $\begin{array}{l}\text { Modelled initial porewater } \\
\text { composition }\end{array}$ & $\begin{array}{l}\text { Analysed test water } \\
\text { composition (mean of } \\
\text { initial and final) }\end{array}$ \\
\hline $\mathrm{pH}$ & 7.01 & 7.74 \\
\hline pe & -2.74 & \\
\hline Elements & Concentration $\left(\mathrm{mmol} / \mathrm{kg}_{\mathrm{w}}\right)$ & \\
\hline $\mathrm{Cl}$ & 300 & 262 \\
\hline $\mathrm{Br}^{1}$ & 0.6 & 29.0 \\
\hline $\mathrm{S}(6)$ & 15.0 & 14.8 \\
\hline TIC & 3.16 & 1.3 \\
\hline $\mathrm{Na}$ & 257 & 256 \\
\hline $\mathrm{K}$ & 1.96 & 1.45 \\
\hline $\mathrm{Ca}$ & 16.7 & 15.8 \\
\hline $\mathrm{Mg}$ & 19.9 & 18.0 \\
\hline $\mathrm{Sr}$ & 0.43 & 0.33 \\
\hline $\mathrm{Fe}$ & 0.14 & \\
\hline $\mathrm{Si}$ & 0.18 & \\
\hline $\mathrm{Al}$ & $21.410^{-6}$ & \\
\hline${\text { Acetic } \text { acid }^{2}}^{2}$ & 0.2 & \\
\hline Methane $^{3}$ & 0.035 & \\
\hline
\end{tabular}

$770{ }^{1}$ From Pearson et al., 2003

$771 \quad 2$ From Courdouan et al., 2007

$772{ }^{3}$ Taken at the value of the first plateau of methane concentration from day 116 to day 529 
774 Table 3. Outcome of sensitivity analysis on organic matter source and clay pH buffer effect.

775

\begin{tabular}{|l|l|l|l|}
\hline & Organic matter & Clay pH buffer & Comment \\
\hline Simulation 1 & $\mathrm{CH}_{2} \mathrm{O}$ & Yes & High alkalinity, low pH \\
\hline Simulation 2 & Acetone & Yes & Low alkalinity, high pH \\
\hline $\begin{array}{l}\text { Simulation 3 } \\
\text { reference } \\
\text { simulation }\end{array}$ & Glycerol & Yes & \\
\hline Simulation 4 & Glycerol & No & High alkalinity, low pH \\
\hline Simulation 5 & Glycerol & Yes $\times 3$ & Almost no effect \\
\hline Simulation 6 & Glycerol & $\begin{array}{l}\text { Yes and initial } \\
\mathrm{pH}=7.4\end{array}$ & Low alkalinity, high pH \\
\hline
\end{tabular}




\section{Figure captions}

778 Figure 1. Profiles of mineral volume changes over a period of 1426 days, without (A) and with

779 ion exchange and biodegradation (B) from Alt-Epping et al. (2006). The vertical line represents

780 the borehole/rock interface. The precipitation of carbonate phases, calcite, dolomite and siderite

781 along with ion exchange with clay surfaces act as buffer for the fluid composition. Increasing

782 chemical complexity leads to a larger volume fraction of carbonate minerals. Sulphate reduction

783 through biodegradation causes pyrite to precipitate.

784 Figure 2. Spatial profiles of selected species concentrations at different times during the

785 simulation from Alt-Epping et al. (2006). The left and right panels are model scenarios without

786 and with ion exchange and biodegradation, respectively. The interface between borehole and

787 surrounding rock is marked by a vertical line. The profiles show that a greater complexity of

788 system processes entails a non-monotonous evolution of species concentration in the borehole.

789 Figure 3. Measurement of organic compounds as a function of time (TOC = total organic carbon,

$790 \quad$ DOC $=$ dissolved organic carbon).

791 Figure 4. Measurements of methane concentrations as a function of time. a: bloom of

792 methanogenic activity. b: decrease in methanogenic activity.

793 Figure 5. $\mathrm{Cl}$ (open circles) and $\mathrm{Br}$ (closed circles) concentrations as a function of time.

794 Figure 6. $\frac{\left\{\mathrm{Na}^{+}\right\}^{z}}{\left\{\mathrm{Me}^{z+}\right\}}$ solute activity ratio as a function of time in the $\mathrm{PC}$ experiments $(\mathrm{Me}=\mathrm{K}, \mathrm{Ca}$,

$795 \mathrm{Mg}$ and $\mathrm{Sr})$. 
796 Figure 7. Comparison between measurements (circles and red dashed line) and $\mathrm{Br}$ and HDO

797 modelled diffusion profiles. Plain and dashed curves are representative of calculations using

798 porosities of 75 or $100 \%$ of the measured total water content. Squares are representative of the

799 sample taken at day twelve while refilling the borehole. The pore diffusion coefficient $\left(D_{p}\right)$

800 remained unchanged at 0.9 and $2.410^{-11} \mathrm{~m}^{2} \mathrm{~s}^{-1}$ for anions and HDO respectively. Upper left

801 figure: $\mathrm{Br}$ concentration in the borehole as a function of time. Upper right figure: focus on the

802 initial stage of the experiment. Bottom left figure: HDO concentrations in the borehole as a

803 function of time. Bottom right figure: $\mathrm{Br}$ concentration ratio profile in the rock at the end of the

804 experiment. The distance is expressed in the bedding plane geometry (see Koroleva et al., this

805 volume).

806 Figure 8. Comparison of experimental results and model using glycerol as the organic carbon

807 source. Top left figure: organic matter. Plain line $=$ acetate; dashed line $=$ TOC $(=$ acetate + solute

808 organic source). Top right figure: sulphate concentration. Bottom left figure: methane

809 concentration. Bottom right figure: evolution of kinetic rates as a function of time.

810 Figure 9. Saturation index of calcite as a function of time.

811 Figure 10. Left: total inorganic carbon (squares) and alkalinity (circles) as a function of time.

812 Right: $\mathrm{pH}$ (solid black line) as a function of time. Lines are indicative of modelled total inorganic

813 carbon and $\mathrm{pH}$ according to the following scenario (organic carbon release in solution / solid

814 source of carbon): 1- $\mathrm{CH}_{2} \mathrm{O} / \mathrm{CH}_{2} \mathrm{O} ; 2$ - Acetone / Acetone; 3- Glycerol / glycerol.

815 Figure 11. Left: total inorganic carbon (squares) and alkalinity (circles) as a function of time.

816 Right: $\mathrm{pH}$ (solid black line) as a function of time. Lines are indicative of modelled total inorganic

817 carbon and $\mathrm{pH}$ according to the following scenario (organic carbon release in solution / solid 
818 source of carbon): 4- Glycerol / Glycerol without pH buffer of clay surfaces; 5- buffering

819 capacity $\times 3$; 6- porewater $\mathrm{pH}$ at 7.4 instead of 7 .

820 Figure 12. Left: sulphide concentration as a function of time. Right: iron concentration as a

821 function of time (note that the concentration is in log scale). Lines are indicative of modelled

822 concentrations (Scenario 3 with glycerol).

823 Figure 13. Concentrations of major cations as a function of time. Circles: measurements. Lines:

824 model (Scenario 3 with glycerol).

825 Figure 14. Modelled pyrite (red) and amorphous sulphide (blue) solid concentration profile (in

$826 \mathrm{mmol} \mathrm{L}{ }^{-1}$ porewater) after 1846 days of perturbation (Glycerol simulation case).

827 Figure 15. $\mathrm{pH}$ profile after 1846 days of perturbation (Glycerol simulation case). 

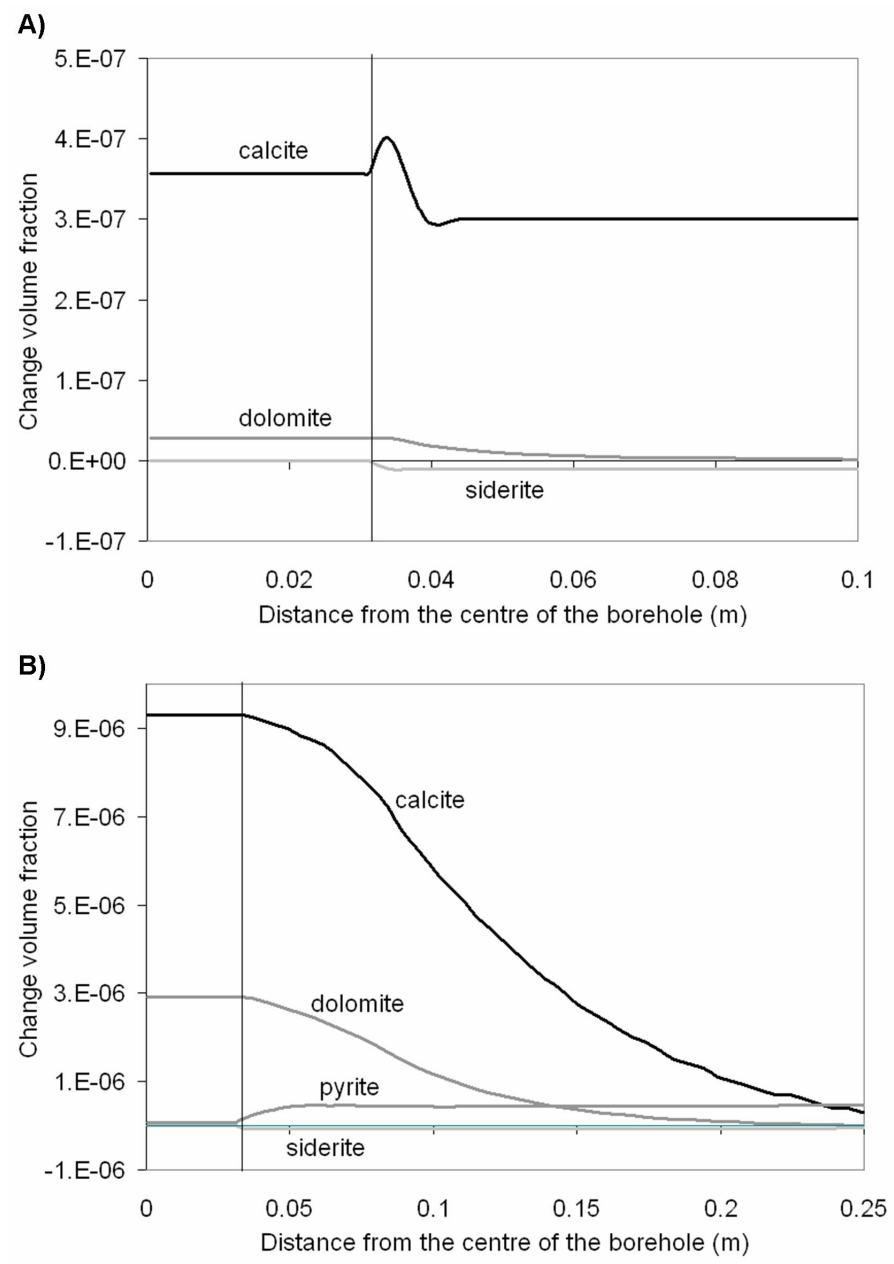

834 Figure 1. Profiles of mineral volume changes over a period of 1426 days, without (A) and with

835 ion exchange and biodegradation (B) from Alt-Epping et al. (2006). The vertical line represents

836 the borehole/rock interface. The precipitation of carbonate phases, calcite, dolomite and siderite

837 along with ion exchange with clay surfaces act as buffer for the fluid composition. Increasing

838 chemical complexity leads to a larger volume fraction of carbonate minerals. Sulphate reduction

839 through biodegradation causes pyrite to precipitate. 

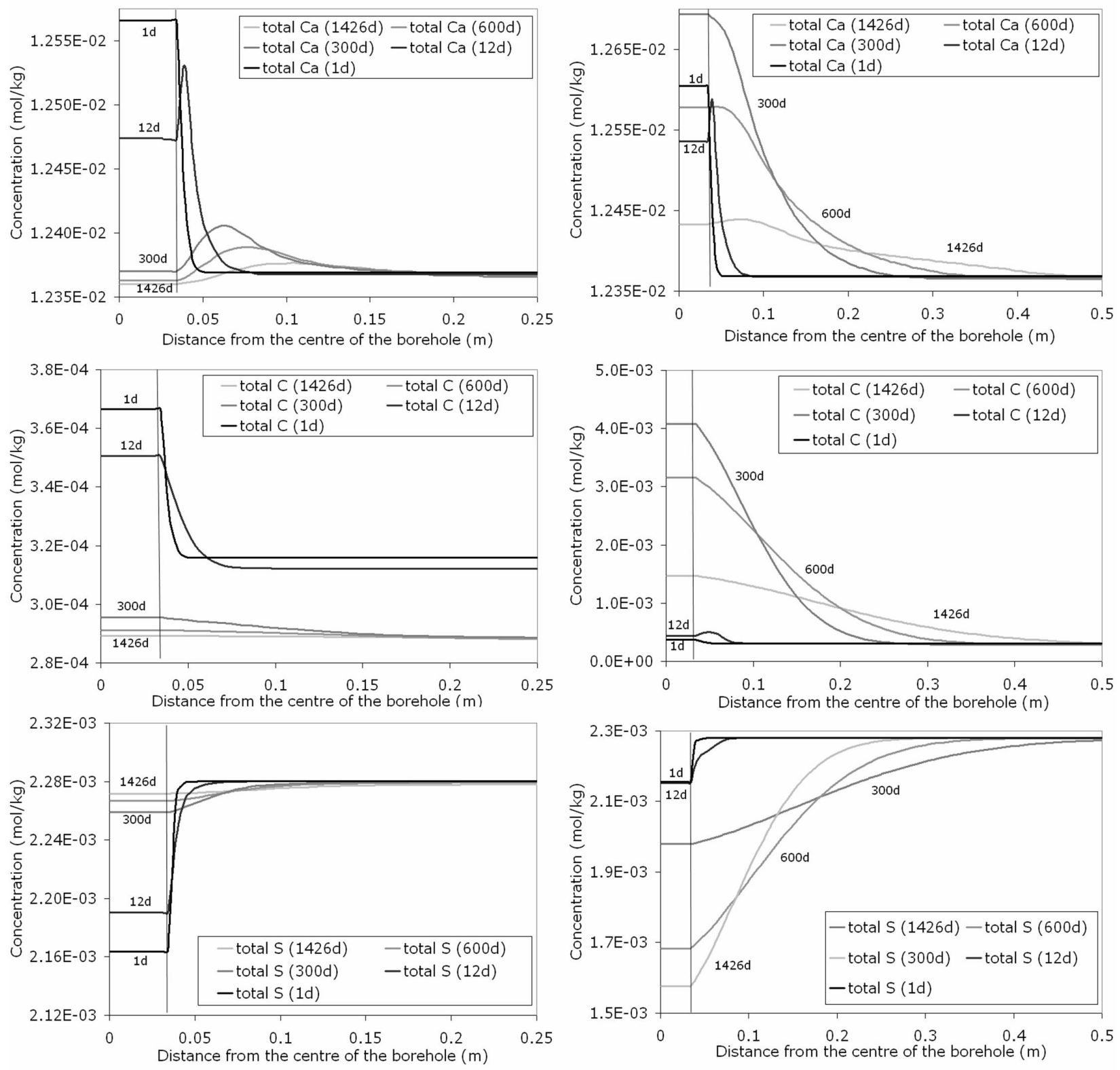

844 Figure 2. Spatial profiles of selected species concentrations at different times during the

845 simulation from Alt-Epping et al. (2006). The left and right panels are model scenarios without

846 and with ion exchange and biodegradation, respectively. The interface between borehole and

847 surrounding rock is marked by a vertical line. The profiles show that a greater complexity of

848 system processes entails a non-monotonous evolution of species concentration in the borehole. 
850

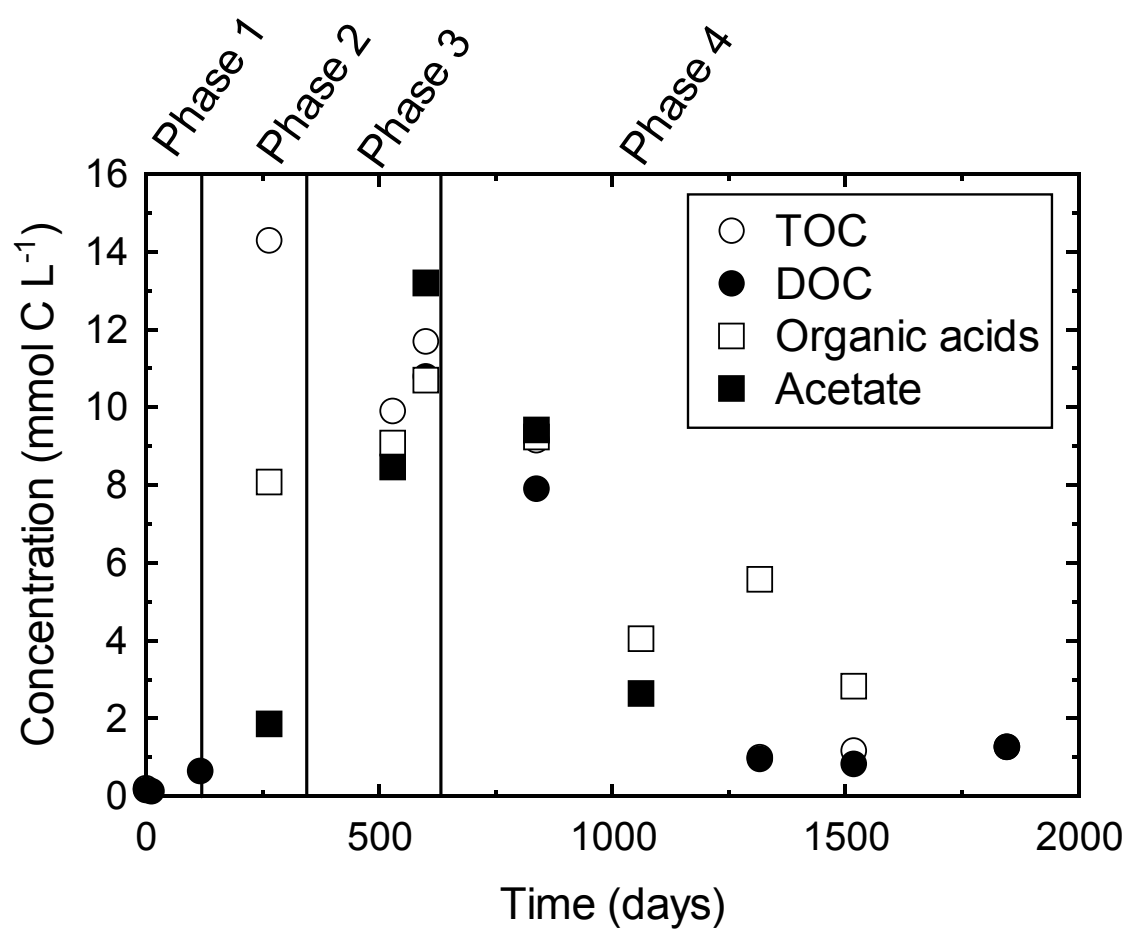

852 Figure 3. Measurement of organic compounds as a function of time in the borehole (TOC $=$ total 853 organic carbon, $\mathrm{DOC}=$ dissolved organic carbon).

854 


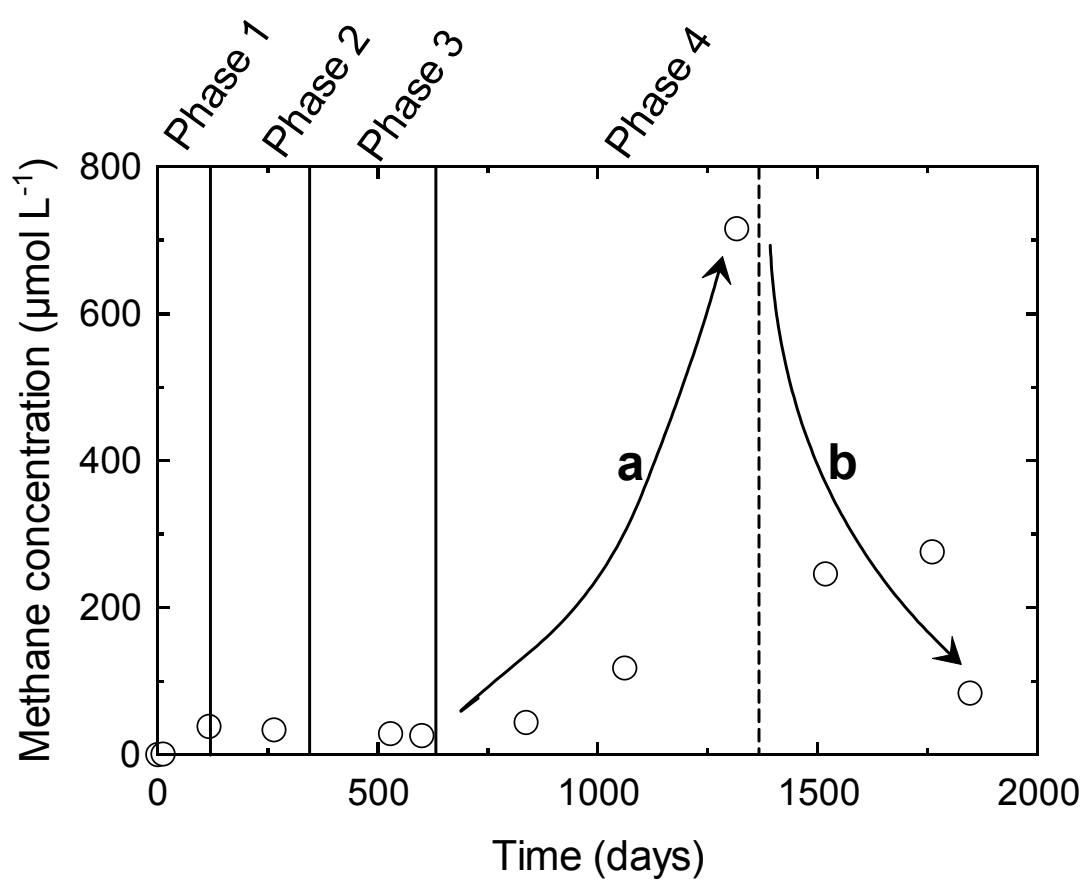

856 Figure 4. Measurements of methane concentrations as a function of time. a: bloom of 857 methanogenic activity. b: decrease in methanogenic activity.

858

859

860

861

862 


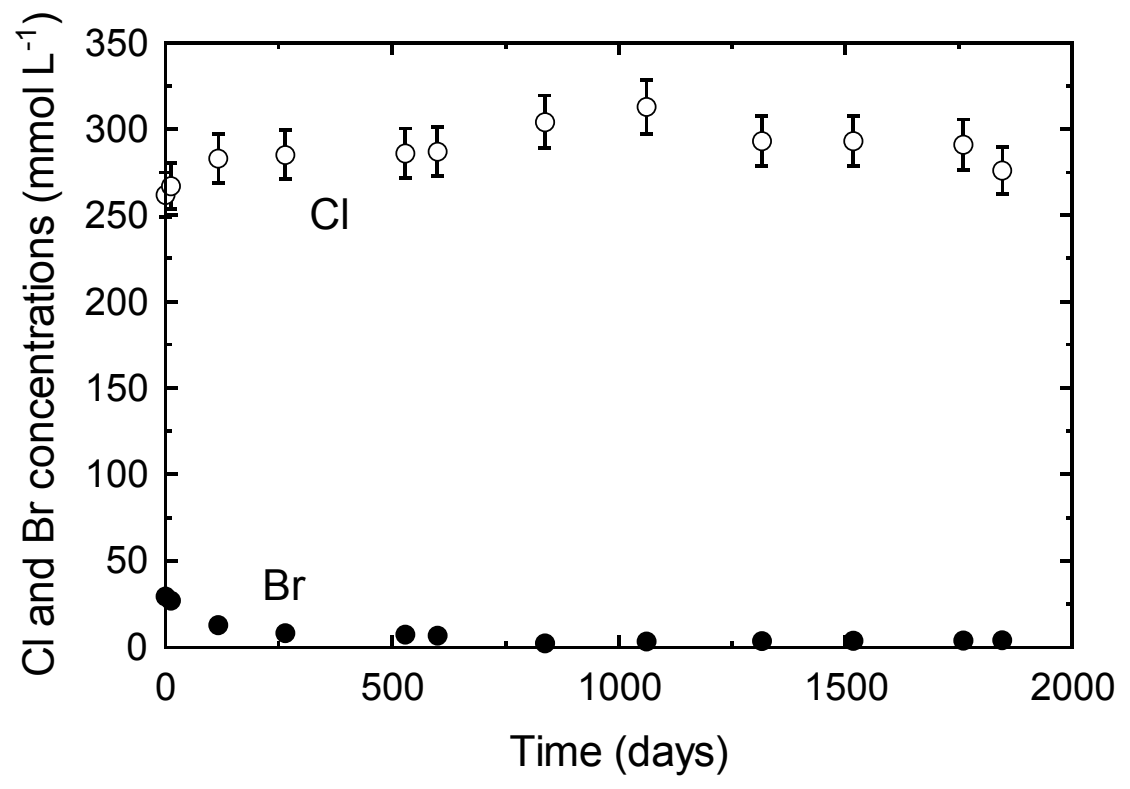

Figure 5. $\mathrm{Cl}$ (open circles) and $\mathrm{Br}$ (closed circles) concentrations as a function of time.

865

866

867

868

869

870

871 

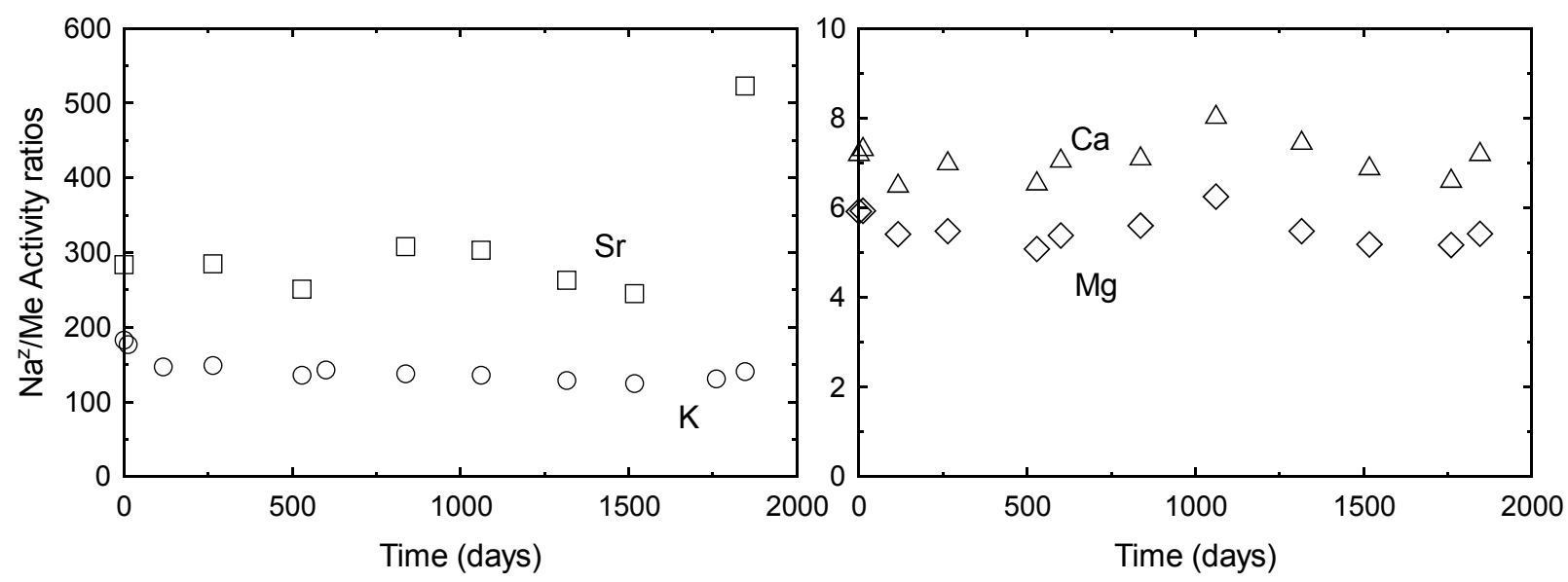

873 Figure 6. $\frac{\left\{\mathrm{Na}^{+}\right\}^{z}}{\left\{\mathrm{Me}^{z+}\right\}}$ solute activity ratio as a function of time in the $\mathrm{PC}$ experiments $(\mathrm{Me}=\mathrm{K}, \mathrm{Ca}$,

$874 \mathrm{Mg}$ and $\mathrm{Sr}$ ).

875

876

877 

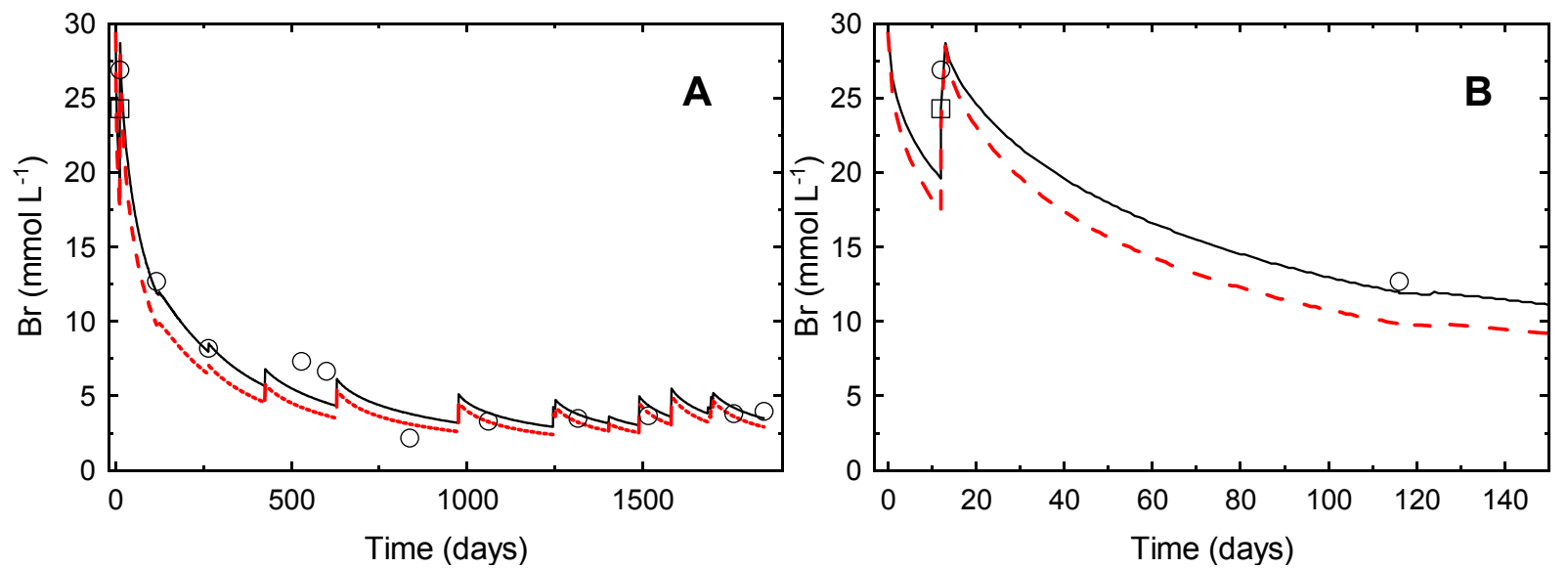

879
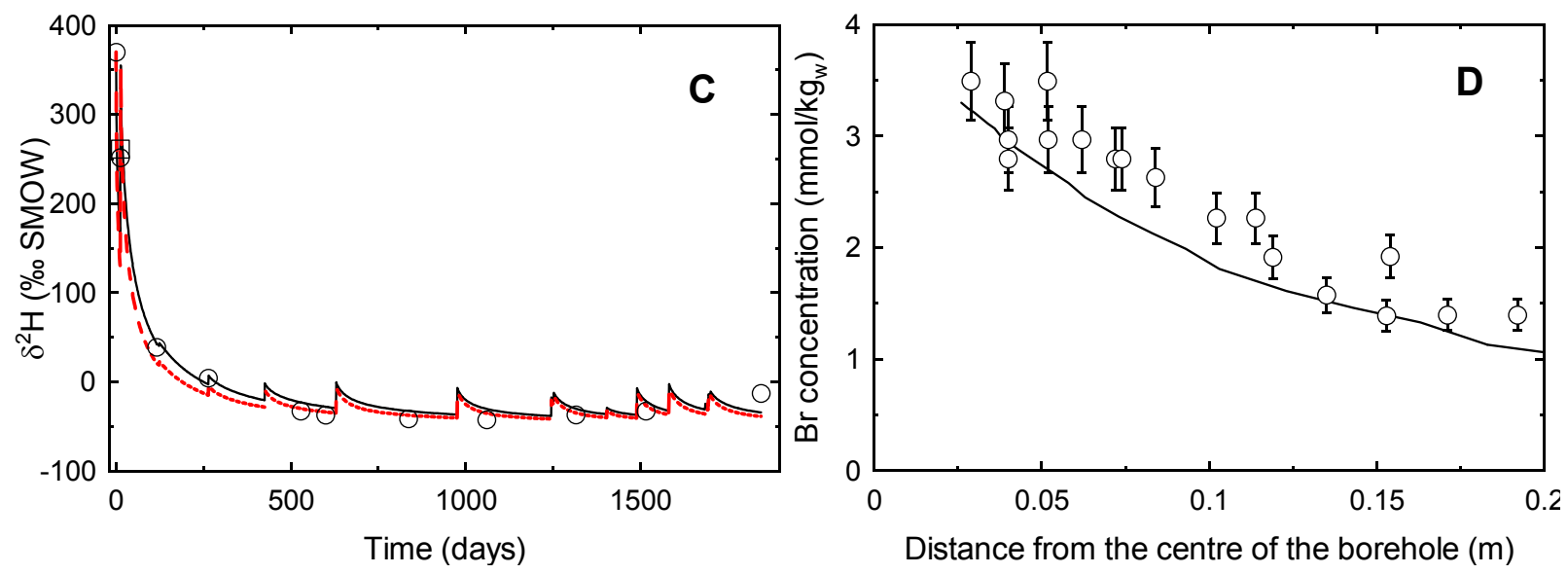

882 Figure 7. Comparison between measurements (circles) and $\mathrm{Br}$ and HDO modelled diffusion 883 profiles (obtained from calibration). Black plain and red dashed curves are representative of

884 calculations using porosities of 75 or $100 \%$ of the measured total water content. Squares are 885 representative of the sample taken at day twelve while refilling the borehole. The pore diffusion 886 coefficient $\left(D_{p}\right)$ remained unchanged at 0.9 and $2.410^{-10} \mathrm{~m}^{2} \mathrm{~s}^{-1}$ for anions and HDO respectively. $887 \mathrm{~A}$ : $\mathrm{Br}$ concentration in the borehole as a function of time. B: focus on the initial stage of the 888 experiment. C: HDO concentrations in the borehole as a function of time. D: Br concentration 889 ratio profile in the rock at the end of the experiment. The distance is expressed in the bedding 890 plane geometry (Koroleva et al., This issue). 

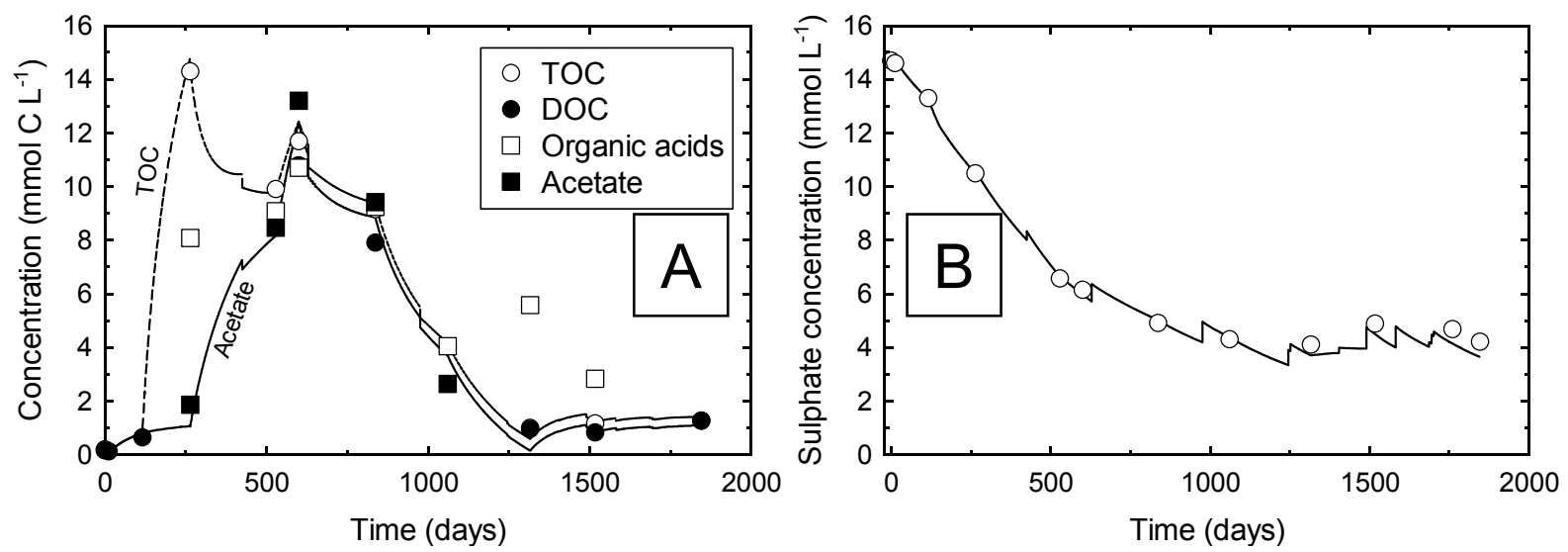

893
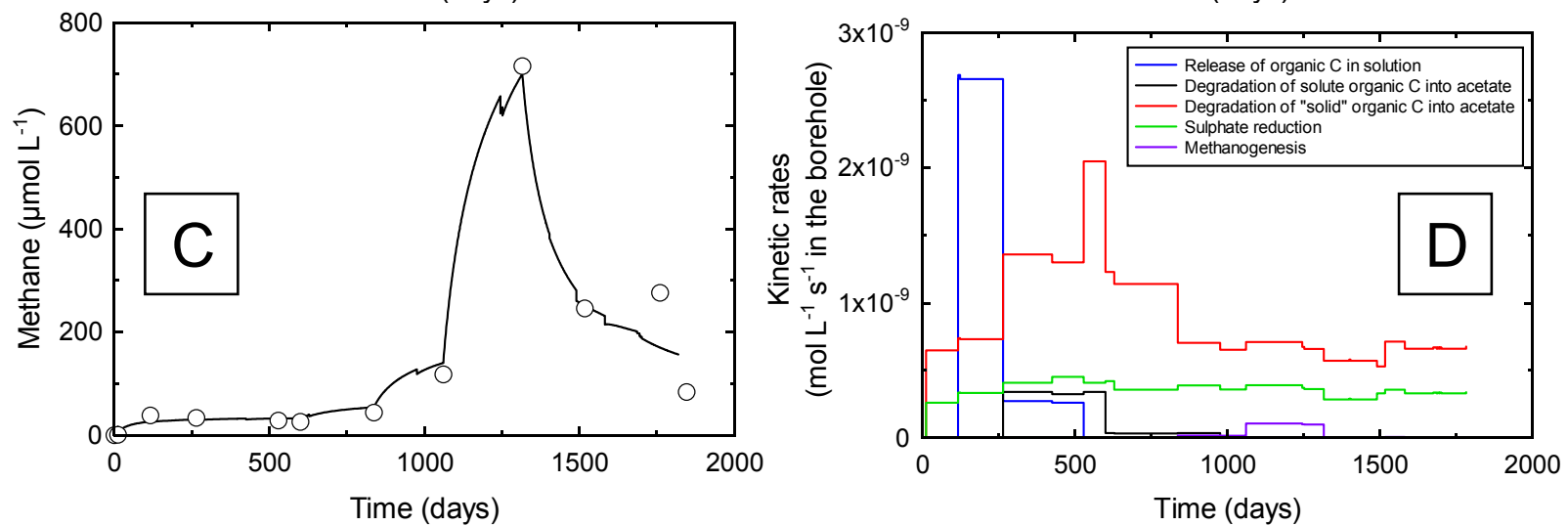

894 Figure 8. Comparison of experimental results and model using glycerol as the organic carbon

895 source. A: organic matter. Plain line $=$ acetate; dashed line $=$ TOC $(=$ acetate + solute organic

896 source). B: sulphate concentration. C: methane concentration. D: evolution of kinetic rates as a

897 function of time.

898 


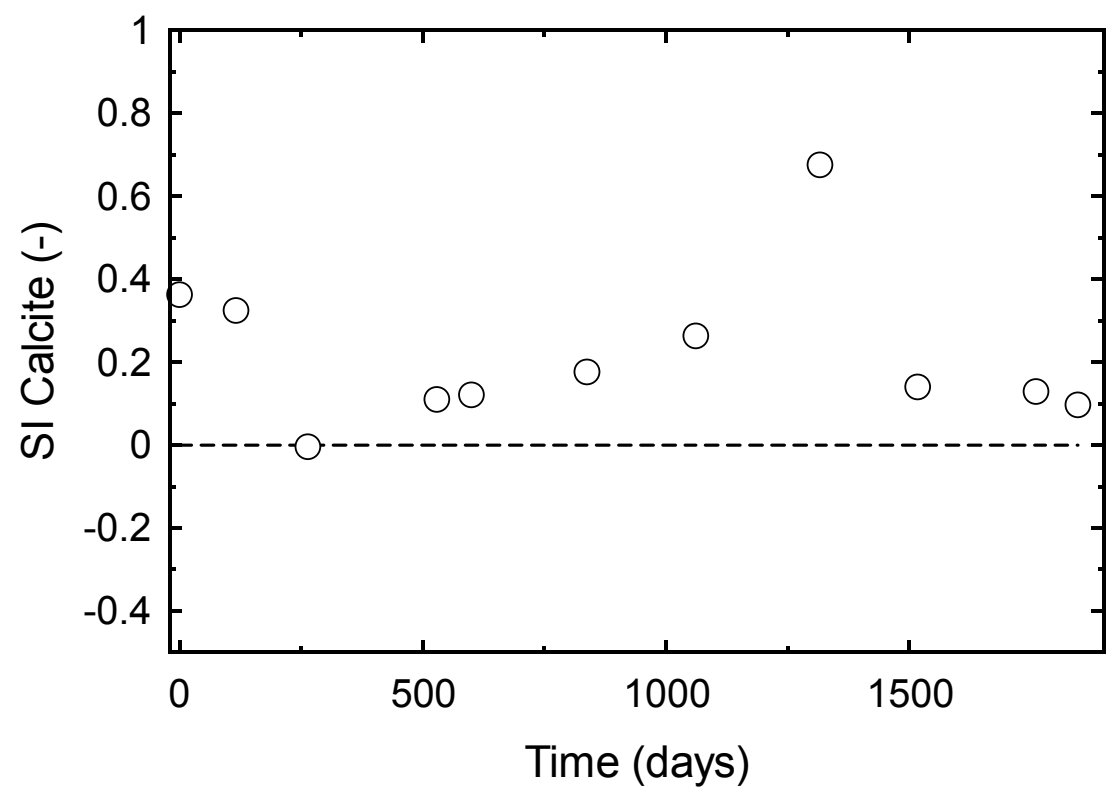

Figure 9. Saturation index of calcite as a function of time.

901

902

903

904

905

906

907

908 

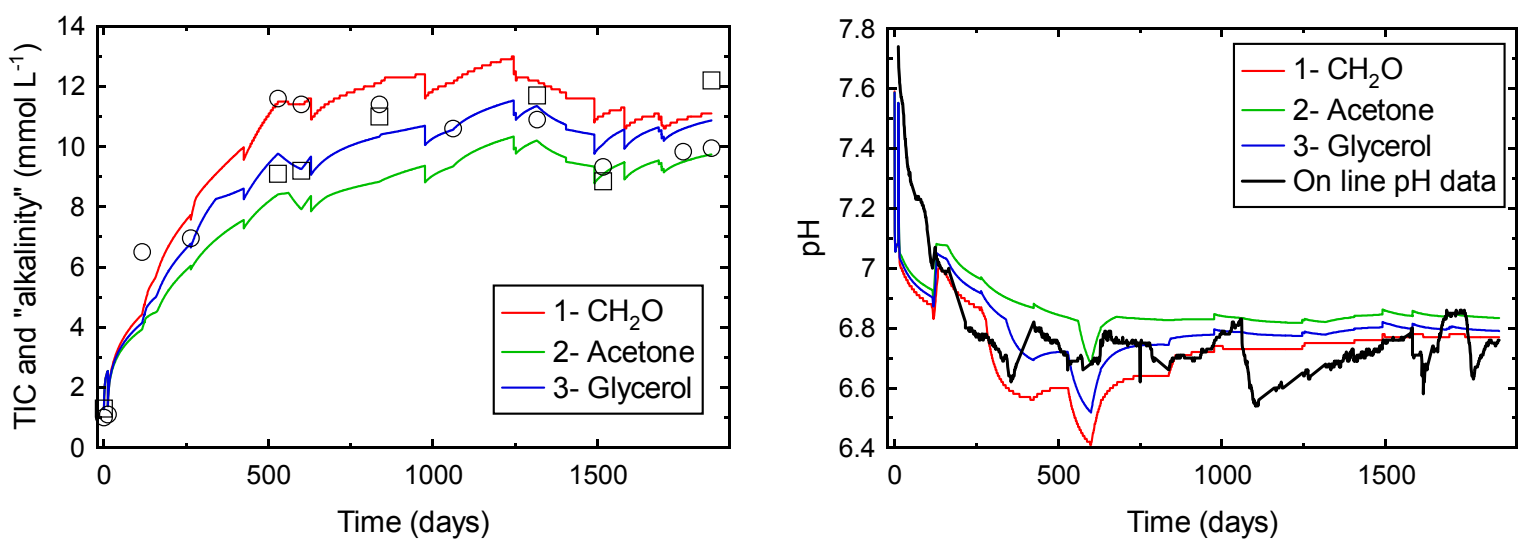

910

911 Figure 10. Left: total inorganic carbon (squares) and alkalinity (circles) as a function of time.

912 Right: pH (solid black line) as a function of time. Lines are indicative of modelled total inorganic

913 carbon and $\mathrm{pH}$ according to the following scenario (organic carbon release in solution / solid

914 source of carbon): 1- $\mathrm{CH}_{2} \mathrm{O} / \mathrm{CH}_{2} \mathrm{O} ; 2$ - Acetone / Acetone; 3- Glycerol / glycerol.

915

916

917 

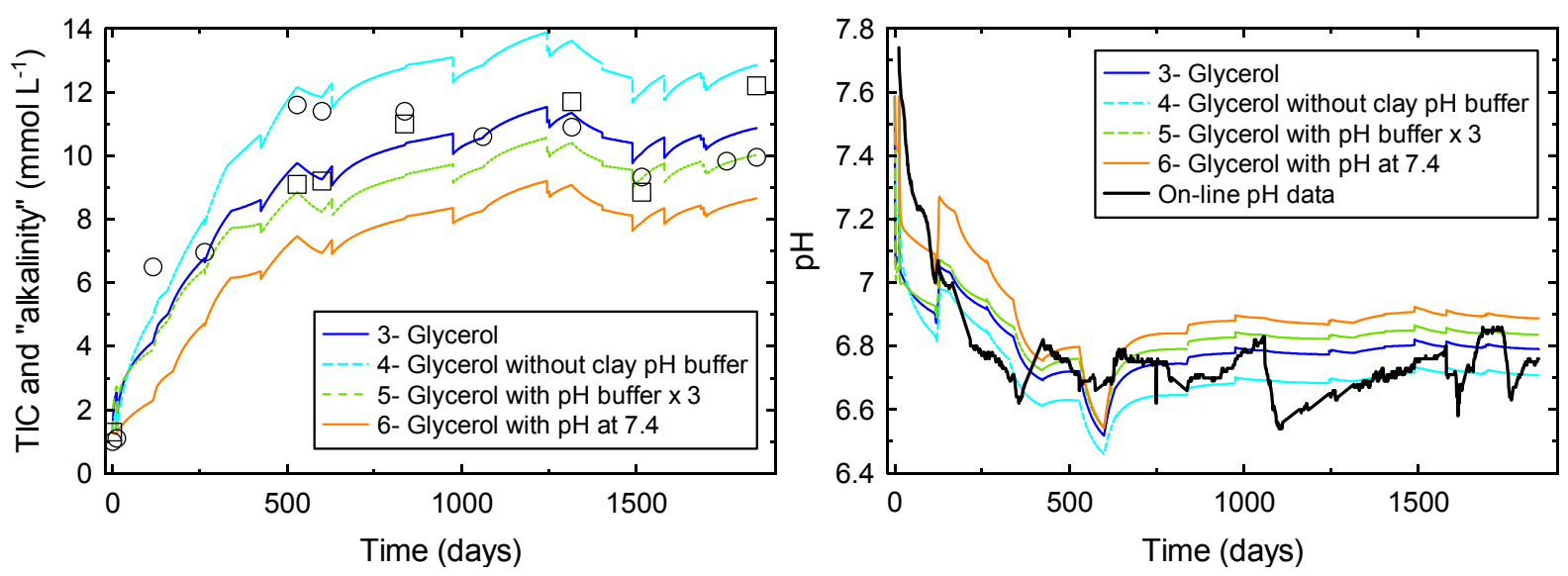

921

922 Figure 11. Left: total inorganic carbon (squares) and alkalinity (circles) as a function of time.

923 Right: $\mathrm{pH}$ (solid black line) as a function of time. Lines are indicative of modelled total inorganic

924 carbon and $\mathrm{pH}$ according to the following scenario (organic carbon release in solution / solid

925 source of carbon): 4- Glycerol / Glycerol without $\mathrm{pH}$ buffer of clay surfaces; 5- buffering

926 capacity $\times 3$; 6- porewater $\mathrm{pH}$ at 7.4 instead of 7 . 

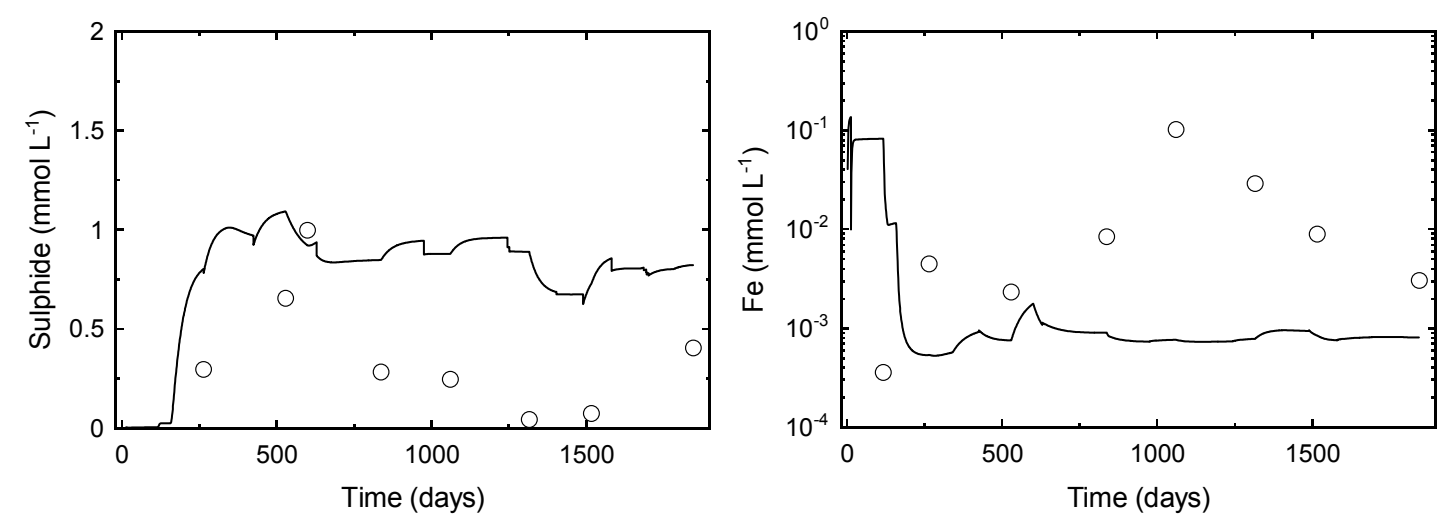

934

935 Figure 12. Left: sulphide concentration as a function of time. Right: iron concentration as a

936 function of time (note that the concentration is in log scale). Lines are indicative of modelled

937 concentrations (Scenario 3 with glycerol).

938

939

940

941

942

943

944

945 

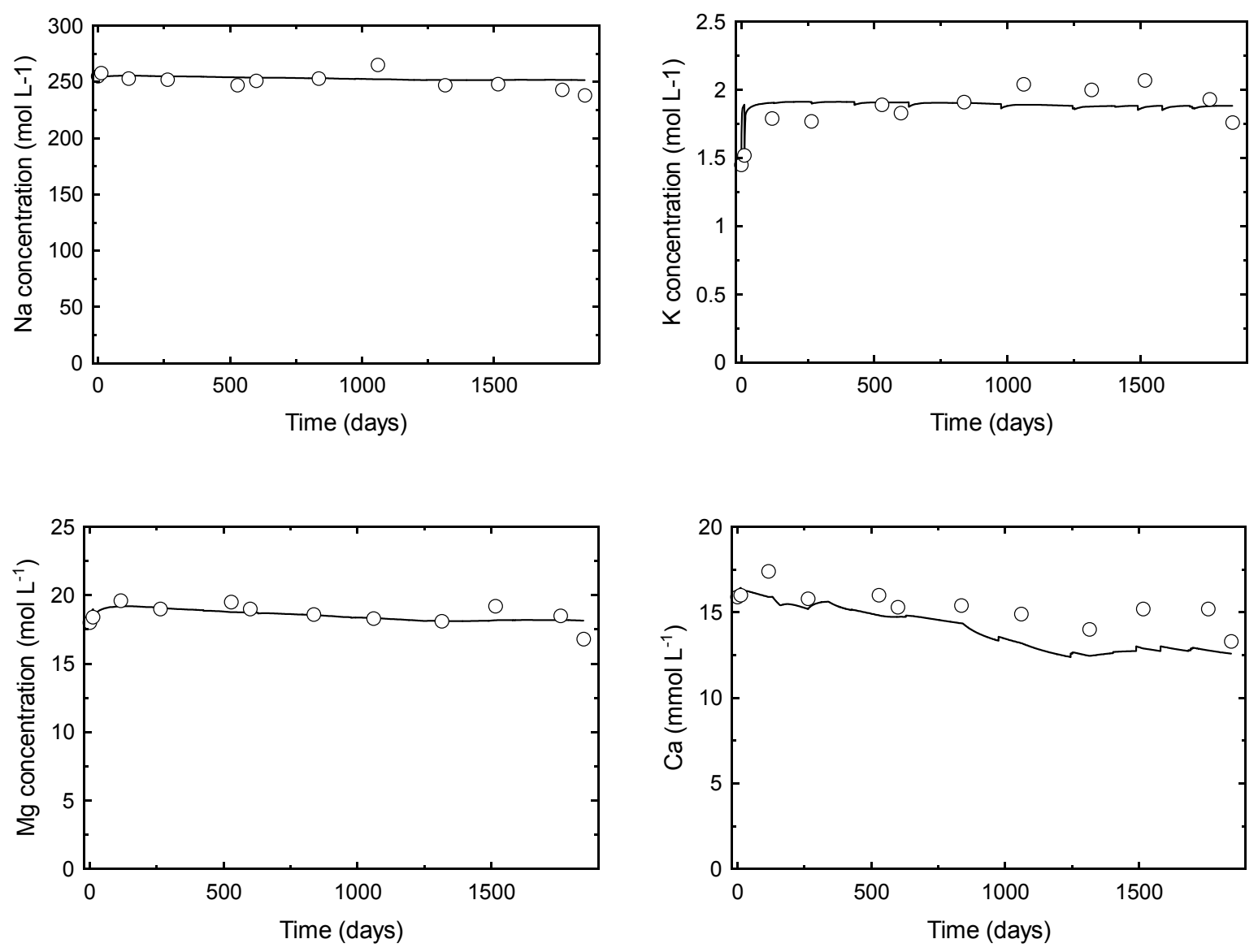

948

949

950 Figure 13. Concentrations of major cations as a function of time. Circles: measurements. Lines:

951 model (Scenario 3 with glycerol).

952

953

954

955 


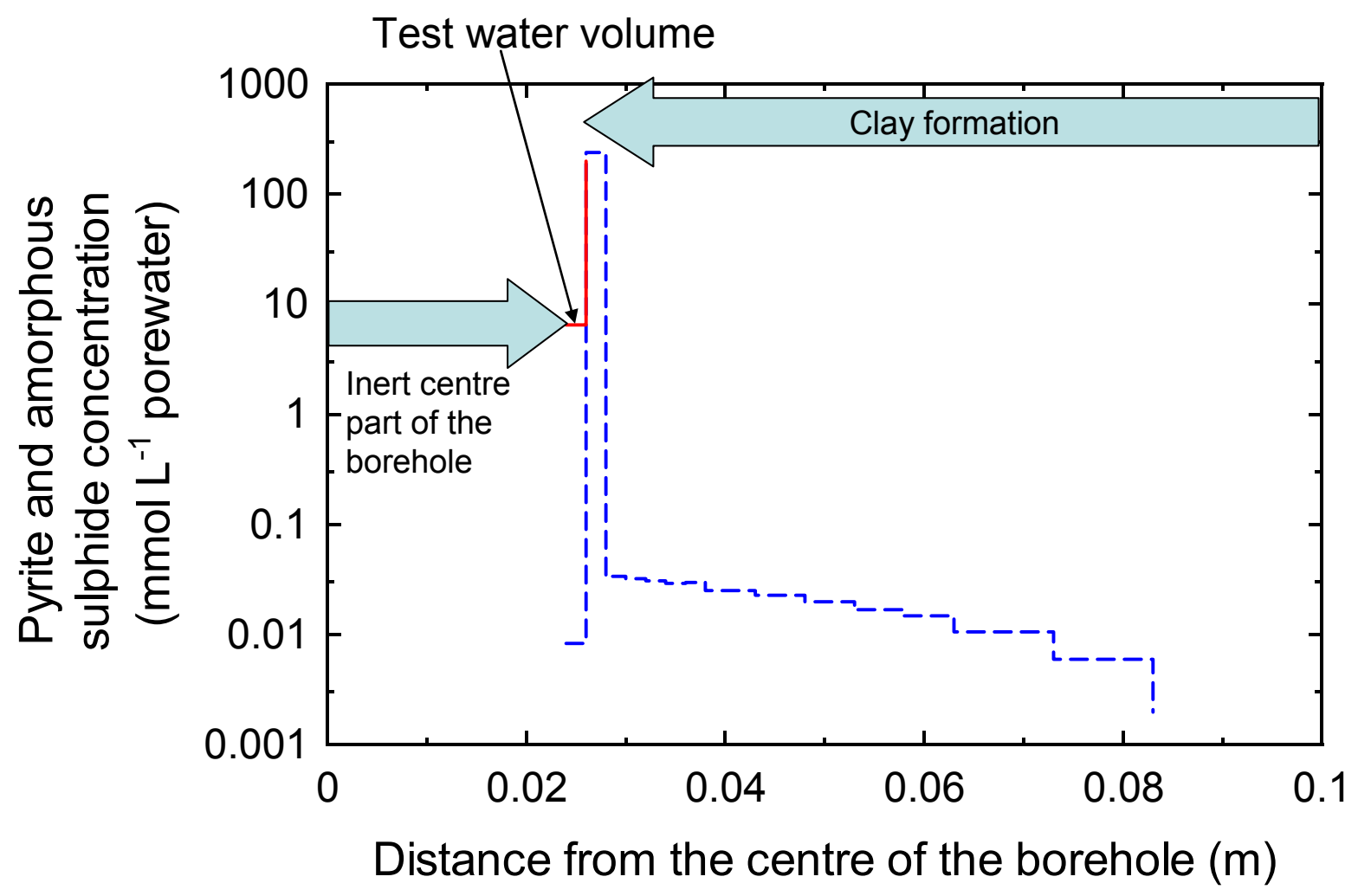

957 Figure 14. Modelled pyrite (red) and amorphous sulphide (blue) solid concentration profile (in

$958 \mathrm{mmol} \mathrm{L}{ }^{-1}$ porewater) after 1846 days of perturbation (Glycerol simulation case).

959

960

961

962 


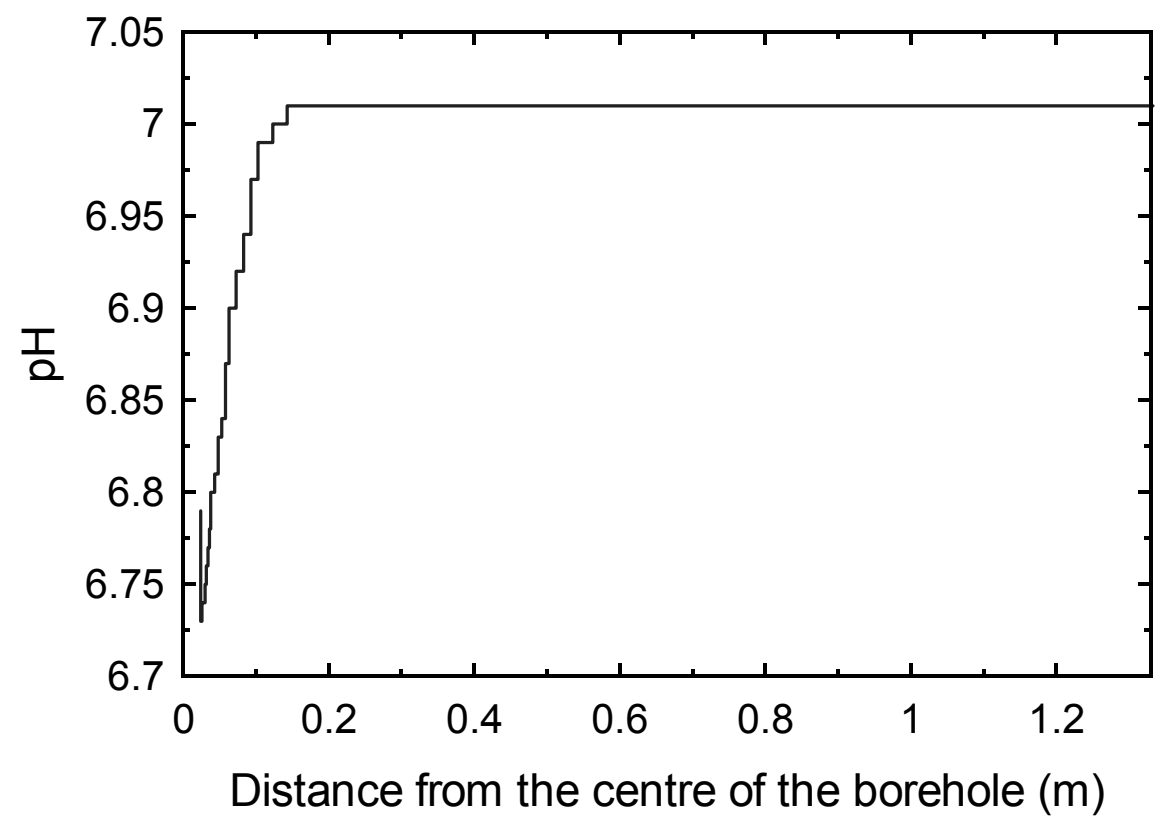

964 Figure 15. $\mathrm{pH}$ profile after 1846 days of perturbation (Glycerol simulation case).

965

966 